\title{
Geçmişten Günümüze Trakya El Dokumaları Yaygilar, Tasarımda Sorunlar ve Çözümler
}

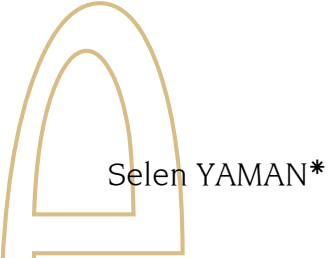

ÖZET

El dokuma yaygılar, kilim ve halı insanların gereksinimi giderme amaçlı yapıldığından, genellikle yapan kişilerce kaygı duyulmaksızın içten gelen duyguların yansitılması sonucu kimi zaman sade, kimi zaman da oldukça ağır motiflerin kullanılması suretiyle estetik ve sanatsal değerler yüklenerek dokunmuştur. Üretim sonucu olan her ürün aslında bir yaratımdır. Yaşamın gerçek belgeleridir.

Dokuma, insanlığın çok eskiden beri yapmış olduğu bir uğraşıdır. Halı ve Kilim dokumacılığının araştırılıp incelenmesi bir anlamda yaşanılan sorunların çözümlenmesi için yeni varsayımların ortaya atılması açısından son derece önem taşımaktadır.

Bugün elde bulunan eski el dokuma yaygılar, kilim ve halı örneklerinin birçoğu müzelerde sergilenmesine rağmen yüzyıllar öncesinden kalan örneklerin sayısı oldukça az ve Trakya bölgesine ait örneklere rastlamak ne yazık ki mümkün değildir.

Anahtar Kelimeler: Trakya, Kırklareli, Dokuma tezgahı, Pomak, Poyralı, Eriş, Düz dokuma yaygılar, Kilim.

\section{Giriş}

Kırklareli'de 19. yüzyıl ortalarına kadar dokumacılık yaygın iken bugün kaybolmaya yüz tutmuş olması acı bir gerçek olarak karşımıza çıkmaktadır. Eski el sanatlarına ait işyerleri kalmamıştır. Sadece köyler-

* Öğretim Görevlisi, Kırklareli Üniversitesi Teknik Bilimler Meslek Yüksekokulu, e-posta: selenyaman@hotmail.com

\section{Design Problems and its Solutions}

\begin{abstract}
Hand-woven mats, rugs and carpets made of people's need for troubleshooting purposes, without concern persons who are usually the result of sincere reflection of the emotions, sometimes simple, sometimes quite heavy loaded motifs woven through the use of aesthetic and artistic values. Each product resulting from a production is actually a creation. They are the surviving documents of life itself

Weaving is a sphere made by mankind for ages. The research on new analysis is in a sense extremely important in terms of creating new assumptions relating to the resolution of the problems faced in Carpet and Rug weaving.

Even though the available old rug and carpet samples are exhibited in museums today, the number of samples that have survived for centuries is rather low and unfortunately it is not possible to come across with samples of Thrace region.

Keywords: Thrace, Kırklareli, Weaving looms, Pomaks, Hub, Eris, Flat-woven mats, Rugs.
\end{abstract}

de herkes kendi ihtiyacı olan peşkir, önlük, bezayağı, dimi dokumalar, çarpana dokumaları, namazlağ, felemen kumaşı, şayak, pala denilen yer dokumaları dokunmaktayken günümüzde ise birçoğu kaybolmuş durumdadır. Evlerde eski örneklerine ait el dokuması halıları bulunmamaktadır. İşyerlerinin olmaması, gerekli önemin gösterilmemesi, yeterli düzeyde sahip çıkılmaması, dağınık ve az sayıda kişinin bu işle uğraşması, dokuyucuların büyük bir bölümünün yaz aylarında tarımsal faaliyetlerin ağır basarak tarlada 
çalışması, fazla tezgâh olmaması gibi nedenler her geçen gün dokuma işleminin azalmasına ve kaybolmasına yol açmıştır. Kişiler sadece kendi ihtiyaçlarını karşılamak üzere bazı köylerde geleneksel dokumalar yapmaktadır. Özellikle Poyralı Köyündeki dokuma ustası Resmiye Hanım ve Kırklareli Kültür ve Turizm Müdürlüğü Folklor(Halk Kültürü)Araştırmacısı Zekeriya Kurtulmuş Bey'in kişisel özverileriyle işlerine gönülden sahip çıkmaları, geleneksel değerlere verdikleri önem dikkate şayandır.

Kültür ve Turizm Bakanlığı'nca; ülkemiz genelinde kaybolmaya yüz tutan el sanatlarımızı yaşatmak, tanıtmak, tahrip ve yok olmasını önlemek, bu sanatların aslına uygun olarak öğretilmesini, eğitilmiş elemanlar ve ustalar yetiştirerek gelecek nesillere el sanatlarımızın aktarılmasını sağlamak amacıyla, 2007 yılında Kırklareli İli, Pınarhisar İlçesi Poyralı Köyünde "Poyralı Köyü Dokumaları" isminde bir kurs açılmıştır. Poyralı Köyünde eğitim-öğretime kapalı ilkokul binasında başlatılan bu kurs, 250 saat boyunca devam etmiş, dokumacılı̆̆ı ninesinden öğrenen 1946 Poyralı Köyü doğumlu Resmiye Gökerbüyük öğreticiliğinde 21 bayan kursiyer yetiştirilmiştir. Bu kurs süresince heybe, yolluk, seccade ve yastık başları dokutulmuştur.

Poyralı Köyünde ki dokunan örnekler incelendiğinde çözgüler siyah pamuk olarak hazırlanmaktadır. 1980' li yıllara kadar yün iplikler eğrilir daha sonra doğal kök boyalarla boyanırken günümüzde ise doğal kökboyama ortadan kalkmış ve iplikler esnaftan alınmaya başlanmıştır. Şu an dokunmamasına rağmen daha önceleri dokunmuş olan tülü denilen kilimlere de köylülerin evlerinde rastlanmaktadır. Kaybolmaya yüz tutmuş olan bu güzel değerlerimize bir an önce sahip çımalı ve üzerimize düşen görevleri yerine getirmemiz gerekmektedir. Bunun için el dokumalarını yapmakta olan köylerimize gereken ilgiyi göstererek yeni projeler üretmeliyiz. İşe, yeni dokuyucu ustaların yetiştirilmesi, tezgâh sayılarının arttırılması için gerekli çalışmaların yapılması ve kilimin turistik eşya olarak ticari önem kazanmasını sağlanmakla başlanmalıdır.

Kırklareli turizmden çok az pay alan bir ilimizdir. Kırklareli İli, Pınarhisar İlçesi'ne bağlı Poyralı Köyü, Dupnisa Mağarası ve İğneada'ya gelen turistlerin geçiş yolu üzerinde olması nedeniyle bir kısım dokumalara pazarlama imkânı oluştursa da bu çok yetersizdir. Dokumayı yapan insanların dokuduklarını satmak için köy dışına çıkabilmelerinin de imkânı yoktur.

Trakya dokumaları, turistin çok olduğu bölgelerde oluşturulacak mağazalarda satılmak üzere, satın alınabilirse veya bu insanların elinden bir şekilde tutulup dokumaların pazarlaması gerçekleştirilirse Trakya dokumacılı̆̆ında devamlılık sağlanabilecektir.

\section{Alevi ve Bektași Kökenli Köylerde Dokumalar}

Alevi ve Bektaşi kökenli toplumlar gittikleri ve egemen oldukları bölgelerde kendilerine has el sanatlarını ve bu sanatlara ilişkin kültürlerini de beraberinde götürmüşlerdir.

\subsection{Alevi ve Bektaşi Köylerindeki Dokumalarda Malzeme Ve Yöntemler}

İlk dokuma tekniklerinde dokuma işlemi dikey olarak adlandırılan sistemde çözgü iplikleri hazırlanıp uçlarına ağırlık bağlanmak suretiyle yapılmış. Bu tip tezgâhlarda (düzen) daha çok keçi kılı dokumalar üretilmiş.

Öncelikli olarak keçi kılları kırpılır ve iyice yıkandıktan sonra dokuma işlemi gerçekleştirilirmiş. Dokunma işlemi esnasında dokumanın daha kolay yapılması için üzerine su serpilirmiş. Keçi kılından genellikle heybe ve atlara torba yapılmıştır.

İlerleyen zaman içerisinde dokuma teknikleri gelişmiş ve yünlü(eriş) dokumacılık başlamıştır. Bu arada yatay düzenlerde dokuma işlemleri yapılmaya başlanmış. Öncelikli olarak kırkılan yünler iyice taranır, yıkanır, kurutulur, sopa ile dövülür ve taranır. Eğirme işleminde iğ yörede elcek adı verilen alet ile gerçekleştirilir. Ĭğ altına takılan ağırlığa da arış denilmektedir. Eğrilen iplikler çile haline getirilir. Çözgü iplikleri dokuma ne kadar uzunlukta yapılacak ise ona göre iki sopa etrafında iplikler dolanarak çözgüler hazırlanarak levende sarılır. Çözgü iplikleri gücülerden ve taraktan geçirildikten sonra dokuma işlemi gerçekleştirilir. Çözgü iplikleri yapılacak dokuma'ya göre bazen siyah, bazen beyaz kimi zaman da alacalı olarak hazırlanmaktadır. Çeşmekolu Köyü'nde ise siyah ve beyaz yani köylülerin deyimiyle alacalı pamuk ipliğinden hazırlanmaktadır. ${ }^{1}$ Ancak Muratlı tarafında ki çözgüler kırmızı olarak hazırlanmaktadır. ${ }^{2}$

Lüleburgaz'da yaşayan Hatice Dalkıran tezgâhında halen dokuma işlemleri yapmaya çalışmaktadır. Öncelikli olarak çözgü ipliklerini hazırlayabilmek için çile halindeki iplikler çıkrık sayesinde bobinlere sarılmakta ve daha sonra sarılan bobinler duvara dayalı çağlığa dizilir. Hazırlanan bobinler sıralanarak taraktan geçirip, tambur etrafından dolaşan ipliklerde levende sarmakta. Çift tarak dediği sistem önde ve arka bir tarağın birleştirilmesi suretiyle hazırlanmış. Ancak ön tarak düz arkadaki tarak ise iki tel arası kaynakla birleştirilerek hazırlanmıştır. Bunun sebebi ipliklerin daha düzenli sarılmasını sağlayarak çapraza almayı ortadan kaldırmaktır. Böylece aktarma olayına hiç gerek kalmamaktadır. Tamburun

Fatma Baykal'ın şifahen verdiği bilgilere göre Çeşmekolu Köyü, İlkokul, Doğum tarihi 1946, 08. 01. 2010

2 Hatice Dalkıran'ın şifahen verdiği bilgilere göre Yenibedir Köyü, İlkokul, Doğum tarihi 1948, 10.01.2010 
yan tarafında bir dişli bulunmakta ve bir diş attığında bir dönüş tamamlanmaktadır. Dişlilerin dönüşü tamamlandığında 180 metre ip sarılmaktadır. Levent düzene takıldıktan sonra iplikler gücülerden ve taraktan geçirilip dokuma işlemine başlanmaktadır. ${ }^{3}$

\subsection{Alevi ve Bektaşi Köylerindeki Dokumaların Adları}

Bölgedeki kadın ve erkek kıyafetleri incelendiğinde her birinin tezgâhta dokunduğu ve özelliklerine göre adlandırıldıkları görülmektedir.

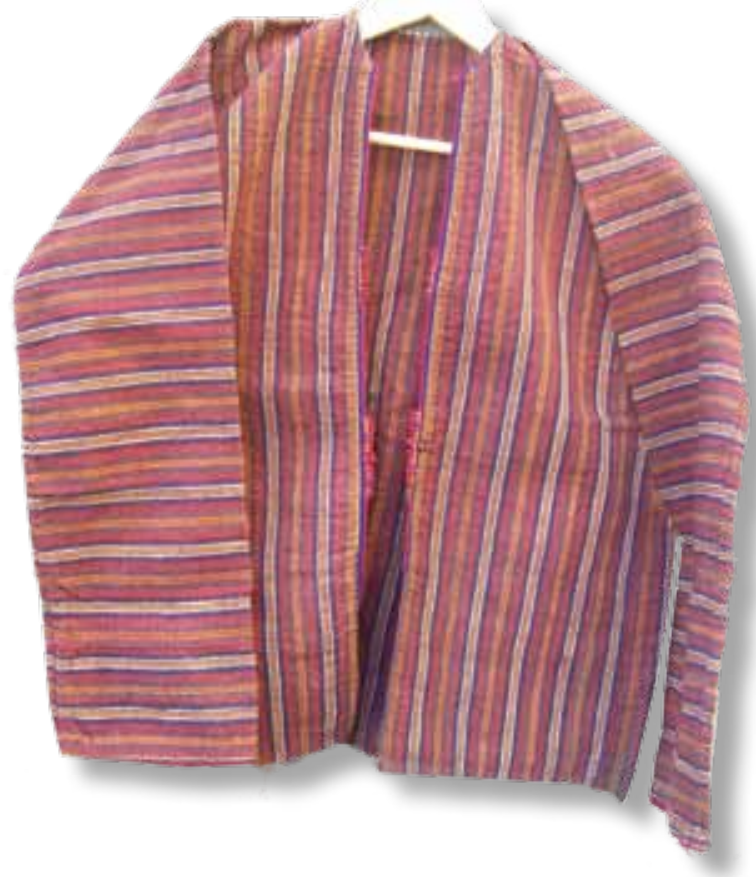

Foto 1. Selen Yaman'a ait. 23.10.2010. Bezayağı tekniğinde, kök boya ile boyanmış ve eriş (yün) iplik kullanılmış Alacaba dokuma

Alacaba: Bezayağı tekniğinde kök boya ile boyanmış eriş (yün)iplikli çizgili dokumalardır.

Bürümcük Gömleği: Bürümcük kumaşlar ipek ve pamuk ipliği kullanılarak dokunmuşlardır.

Bohça Fıtası: 1,3 iplikleri çalarak düz yer altta çalınan yer üstte olmak koşuluyla, küçük çiçekler oluşturularak yapılan dokumalardır. Adından da anlaşılacağı gibi evlenecek kızın çeyizini sarmak veya torba gibi dokunuyorsa içerisine doldurmak amacl için yapılan dokumalardır.

Cepken: Gömleğin üzerine giyilir, yelekte denilmektedir. Çok ince eriş ipliği kullanılarak bezayağı tekniği ile dokunan kumaşların üzerine işleme yapılarak kullanılmıştır. Son dönemlerde saten ya da ipekten yapılmakta, alıcı renklerle süslenmektedir. Ön kısmı işlemeli veya sırmalarla süslüdür. Astarlı olarak yapılanların içine pamuk doldurulmaktadır. Bunlara salta adı verilmektedir.

Hatice Dalkıran'ın şifahen verdiği bilgilere göre Yenibedir Köyü, İlkokul, Doğum tarihi 1948, 10.01.2010
Gocuk: Paltoya verilen isimdir. Genellikle içi tüylü dokumalardır. Sadece yeşil renkli eriş (yün) iplik kullanılarak dört gücü (Çözgü iplerinin aşağı yukarı hareketini sağlayan parça) ile dokunmaktadır. Dört gücü ile dokunmasının sebebi dimi örgülerin yapılması ve dokunan kumaşın daha yumuşak olmasını sağlamaktır.

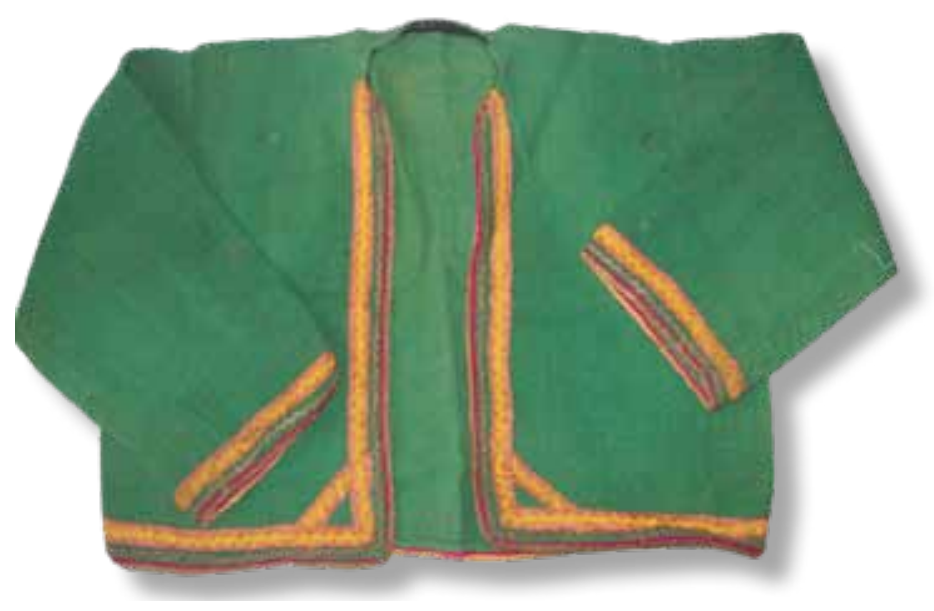

Foto 2. Selen Yaman'a ait. 23.10.2010.Yeşil renkli eriş iplikle, bezayağı tekniği ile dokunan gocuk örneği

Fıta- çımbarlı fıta: Arkaya tahta geçirilir. Tahta kaldırıldıktan sonra iplikler şişe geçirilerek

1-3,3-5 çıkarak dokuma işlemi yapılmaktadır. Şalvarların üzerine takılır. Cenazeye giderken giyilenleri siyahtır. Kullanılan iplik eriştir (yün). Çözgüler siyah, atkılarda ise siyah ve beyaz iplik kullanılarak bezaya$\breve{g} ı$ tekniğinde dokunmuşlardır. Tekirdağ bölgesinde hota denilmektedir.

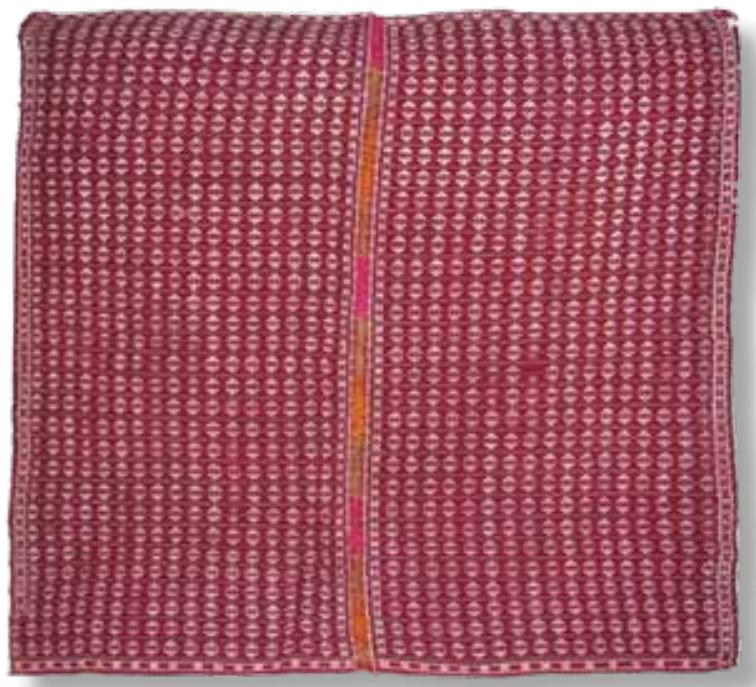

Foto 3. Sevim Güçlü'ye ait Kırklareli. 10.01.2007. Fıta Dokuma İki parça olarak dokunmuş ortadan sonradan elde birleştirilmiş.

Fistan: Mistan da denilmektedir. Bugünkü gömleğin yerine şalvar üstüne giyilmektedir. Şile bezi, basma ve divitin üzerine işleme yapılmaktadır. 
Ferace: Siyah veya yeşil eriş iplik kullanılarak bezayağı örgülü dokumalardır. Bezayağı örgü dokumalar için 2 gücü dimi örgülü kumaş dokumaları 4 gücü kullanılmaktadır. 4 gücü olarak yapılan dokumalar daha yumuşaktır. Siyah feracelerin iplikleri kızılağaç kabuklarının tuzlu suda kaynatılmasıyla elde edilen boyarmadde ile yeşil renkli feracelerin iplikleri lahana turşusunun suyunda bekletilerek boyanmıştır. Osmanlı döneminde kadınlar sokağa çıkarken ipek veya çuha kumaştan yapılmış ferace, yeldirme veya çarşaf giyerlerdi. Halen köylerde sokağa çıkarken yaşlı kadınlar siyah yeni gelinler ise yeşil ferace kullanırlar. Arkalığı bele kadar olup arka parça ile baş örtülür.

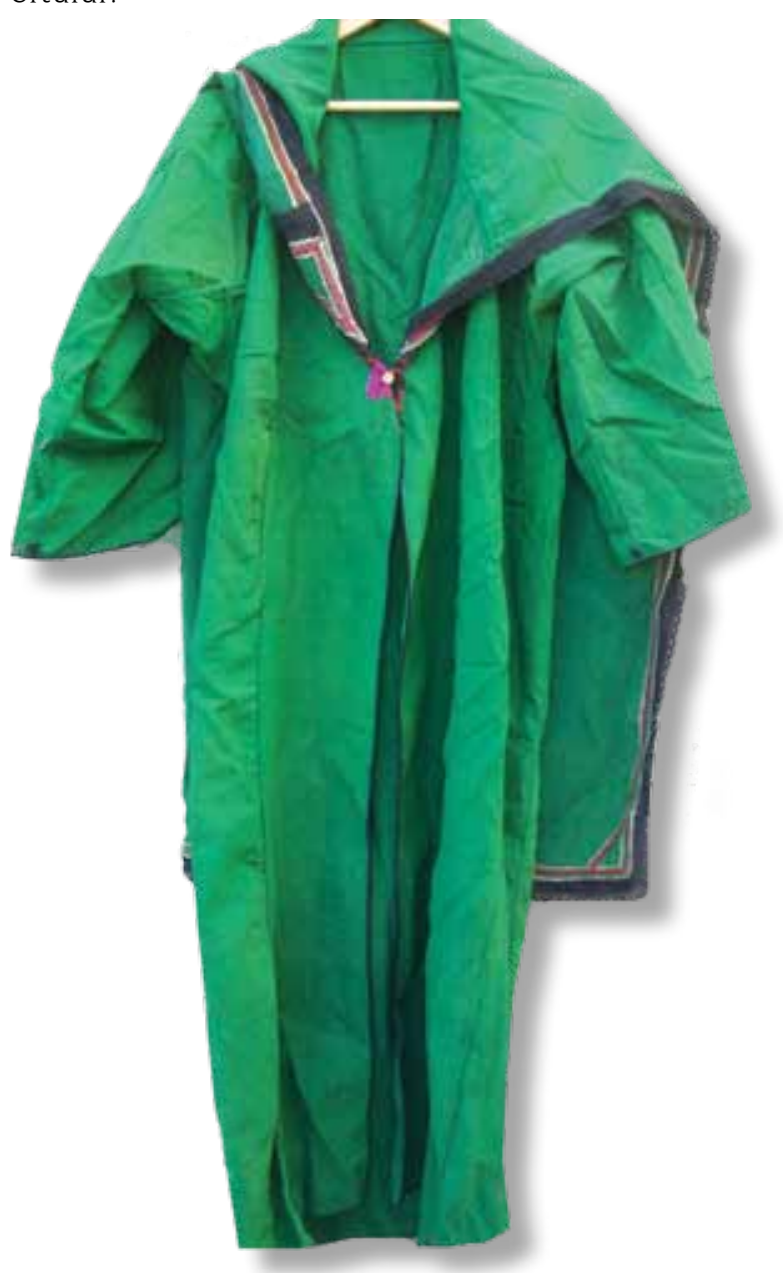

Foto 4. Hatice Kıymetli'den Selen Yaman'a verilmiş. 23.10.2010. Yeşil ferece Hz. Fatma'nın gelinliği olarak kabul edilmektedir. Siyah renklisi matem günlerinde ve yaşlılar tarafından giyilmektedir. Bezayağı tekniğinde, kök boya ile boyanmış, eriş (yün) dokuma.

Mintan: Gömleğe verilen isime denir. Geniş kollu olup yaka kenarları ve etekleri gergefle işlemeli veya oyalı yapılır. Keten veya pamuklu dokumalardır.

Kartopu: Çözgüde beyaz eriş (yün), atkıda altı tel (ip) beyaz eriş (yün) altı tel (ip) beyaz pamuk iplikleri ile çizgili olarak dokunan gömleklik kumaşlara kartopu denilmektedir.

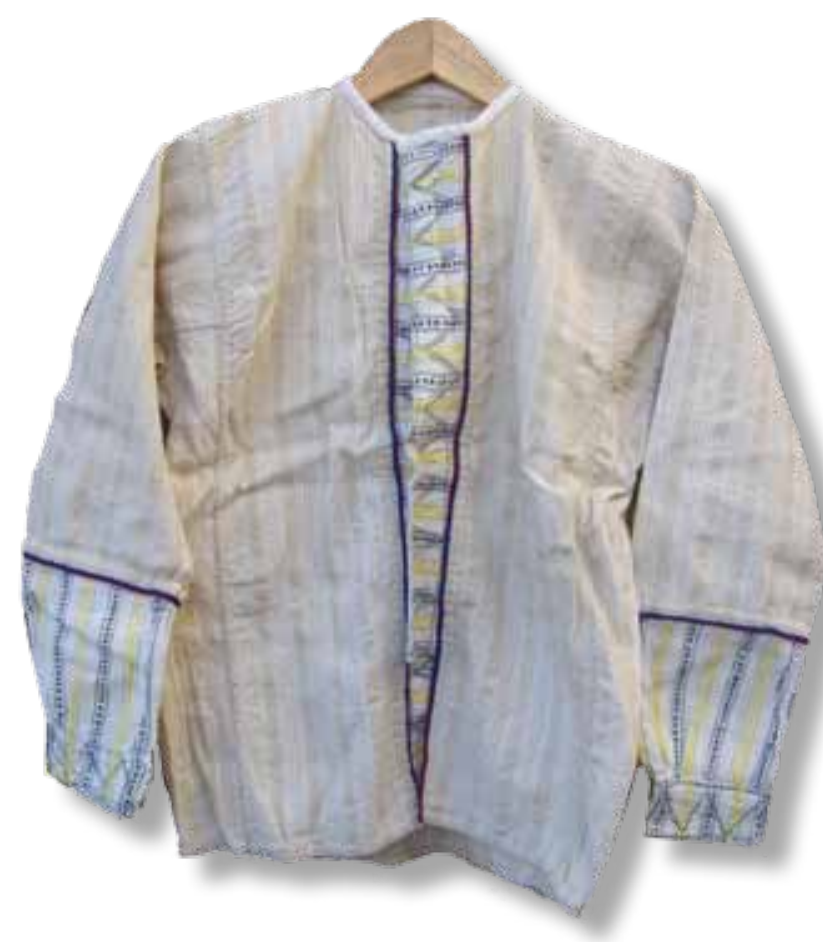

Foto 5. Selen Yaman'a ait. 23.10.2010.Gömleklik pamuk ve eriş(yün) dokuma örneği. Kartopu

Potur: Koyun yapağından ve keçi kılından yapılmış çuha dokumalardan yapılan kaytanlı pantolondur. Yukarı kısma geniş paçaları dardır. Dizden aşağısı düğmelidir.

Sarka: Gömleğin üzerine giyilen kadife dokuma kumaşa işleme yapılarak kullanılır.

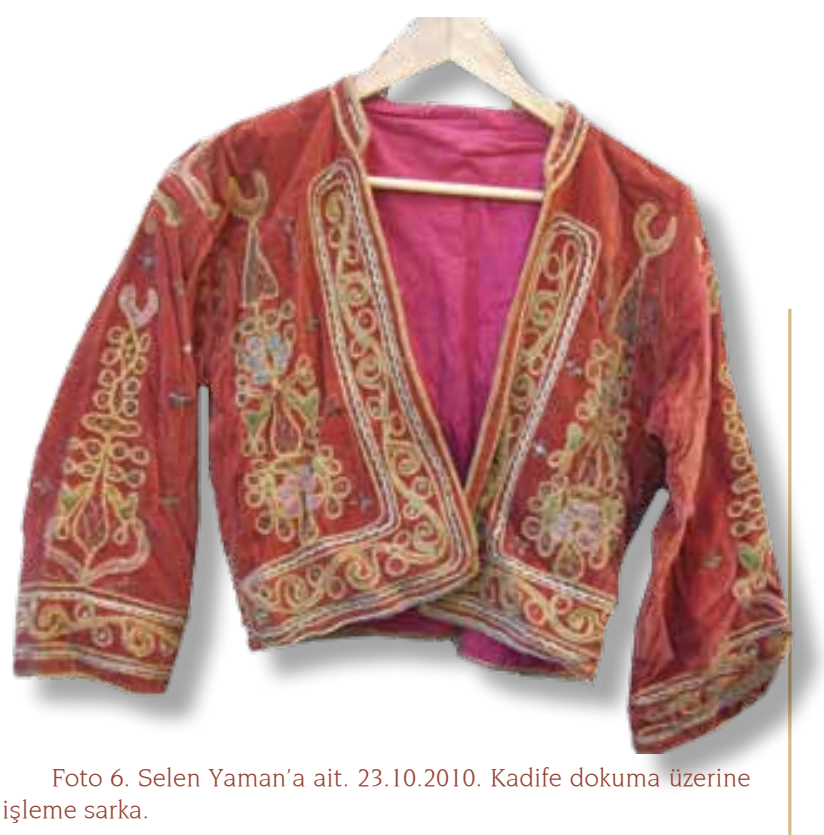

Şalvar: Üst kısmı bol ve büzgülü, paçaları ayrı ve genişçedir. Erkeklerin şalvarları kadınlarınkine göre daha dar ve sadedir. Şalvarlar; yarım ağlı, tam ağlı ve elifli diye adlandırılmaktadır. Şalvarı bele bağlayan kısma uçkur denilmektedir. Eskiden çok ince eriş 
(yün) ipliklerle ve kaliteli dokumalardan yapılmasına rağmen günümüzde desenli basmalardan ve satenler yerini almıştır.

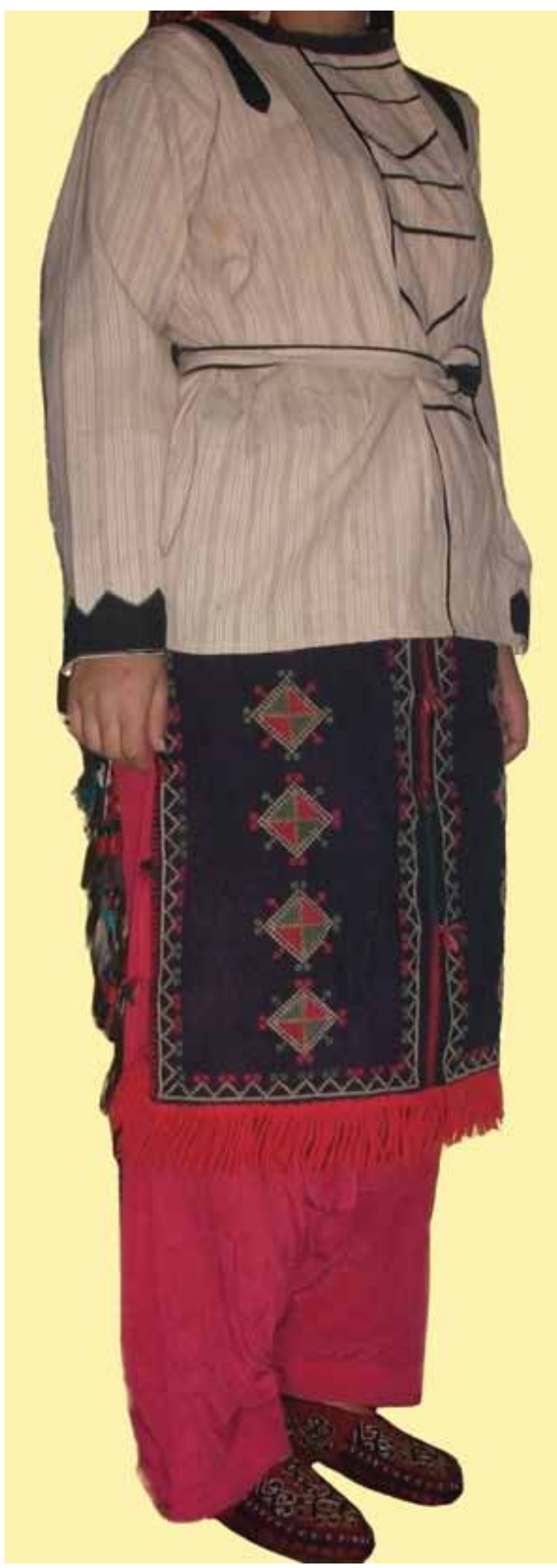

Foto 7. Hadişen Güngördü'ye ait. 18.10.2010. Bulgaristan'dan 1935 yılında gelme gömlek. Yörük fitası. Moraken ipek şalvar. Zincir işlemeli çetik.

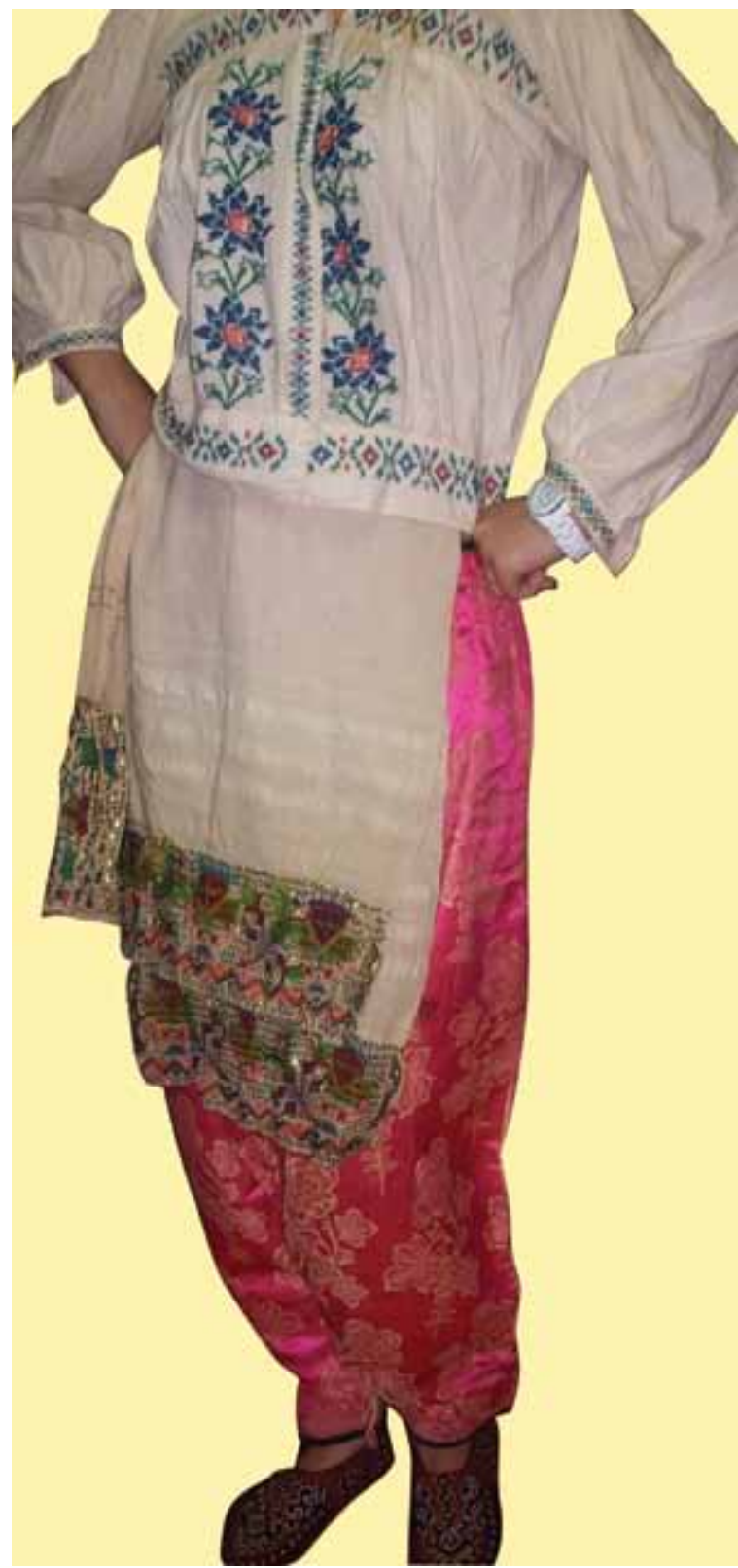

Foto 8. Hadișen Güngördü'ye ait. 18.10.2010. İşleme gömlek Gelin şalvarı üzerine yağlık. Zincir işlemeli çetik.

Uçkur: Yapağıdan yapılan dokumalardır. Şalvar ve poturları bağlamada kullanılır. Lastik görevini yapar.

Kuşak: İki veya üç metre boyundadır ve otuz kırk santim genişliğindedir. Genelde kırmızı renkte olup bele dolanır.

Kırmalı Entari: Beli lastikli tüm bedeni saran pamuklu dokumalardır.

Kebe: Çobanların giymiş olduklarım paltolara verilen isimdir. Şayak dokumalardır.

Çultar, Çimdik: Peluş gibi dokumalardır. Atkı ipi iki ipte bir sopaya dolanarak yapılır. Dört gücü kullanılarak 2:2 dimi örgü kullanılarak yapılan eriş dokumalardır. 


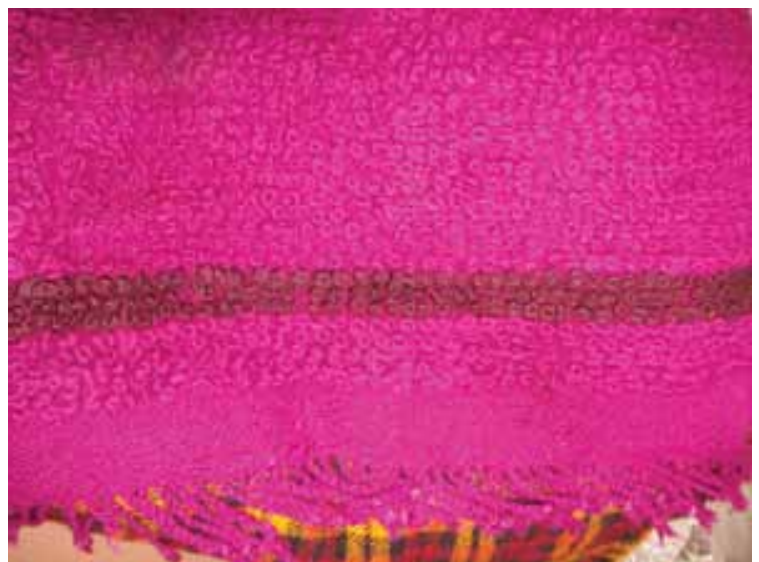

Foto 9. Hatice Dalkıran'a ait, 1948 Yenibedir doğumlu.10.01.2010.Çimdik Dokuma

Bezayağı tekniğinde, kök boya ile boyanmış, eriş (yün) dokuma. Çözgüler pembe hazırlanıyor. Başlangıçta en az 20 sıra kadar pembe iplikle 2:2 dimi örgüsüyle dokuma yapılmış. Daha sonra pembe atkı ipi 2 sırada bir sopaya dolanarak 5 sıra dokunmuş. En az üç sıra koyu kırmızı iplikle aynı işlem tekrarlandıktan sonra pembe renkle dokuma işlemine devam edilmiştir.

Çerge: Battaniye olarak eriş iplikten, bezayağ örgü yapılacaksa iki gücü, dimi örgü kullanılacaksa dört gücüyle yapılan dokumalardır. Üstleri kurdele ile süslenmektedir.

Yatak yüzü: Eriş iplikten, bezayağı örgü yapılacaksa iki gücü, dimi örgü kullanılacaksa dört gücüyle yapılan dokumalardır. Ekose desenli olanları da bulunmaktadır. ${ }^{4}$

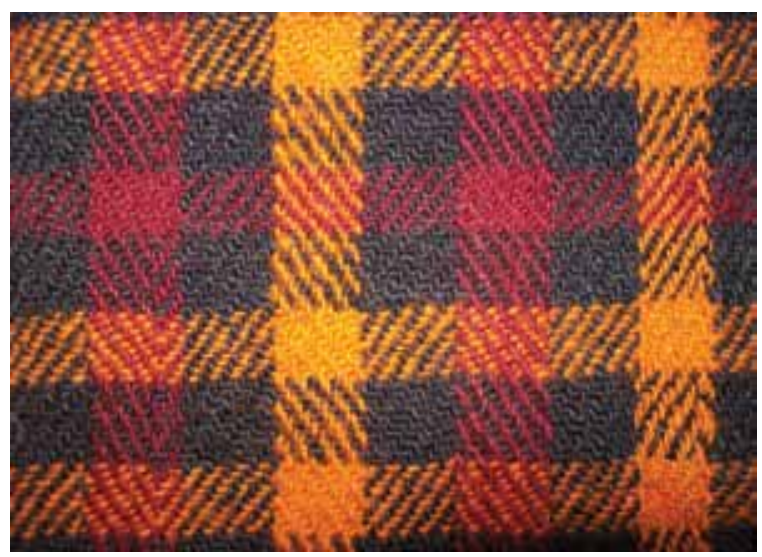

Foto 10. Sevim Güçlü’ye ait Kırklare'li .10.01.2007. Yatak yüzü.

2-2 dimi örgüden türetilmiş Balıksırtı örgüsü tekniğinde dokunmuştur. Kök boya ile lacivert, sarı renklerde boyanmış eriş (yün) iplik kullanılmıştır.Atkı ve çözgüde 12 ip sarı, 12 ip lacivert, 12 ip kırmızı, 12 ip lacivert iplik düzenlemesi ile dokunan ekose yatak yüzü.

4 Hatice Dalkıran'ın 10.01.2010 tarihinde şifahen verdiği bilgilere göre ve http://www.tekirdagkulturturizm.gov.tr (2010)

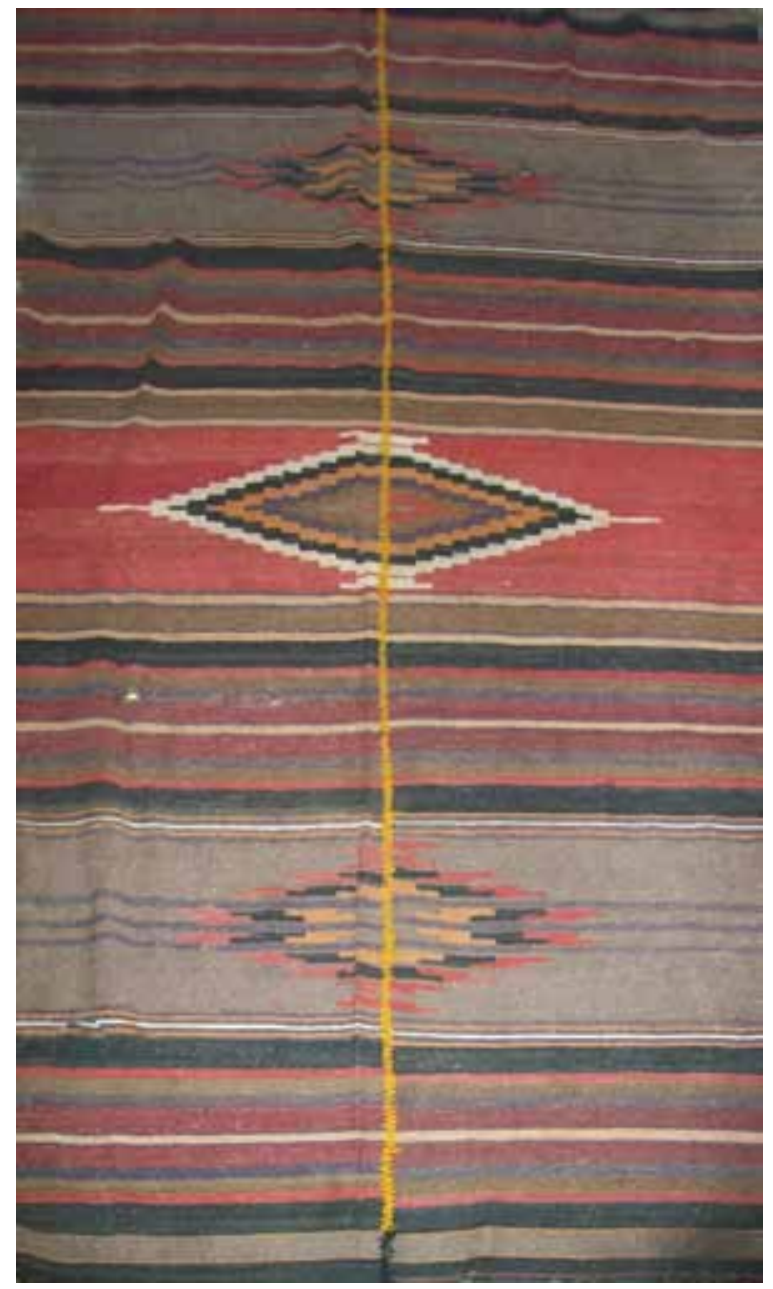

Foto 11. Anneannem Zekiye Demirel'in annesi Ahlatl Köyün'den Zeliha Okur'a ait. 12.01.2010. İlikli Kilim Örneği

Teknik olarak alttan ve üstten çözgülerin arasına, onları örtecek şekilde yerleştirilen renkli atkı iplikleri, komşu motifin değişik renkteki atkısının olduğu alanına geçmeden motiflerin sınırından geri döner, bu iplikler birkaç sıra geri döndüğünde arada dikey bir çizgi meydana gelir ki buna ilik denir. İliklerin bir santimi aşması görünüm ve kullanım açısından sağlıklı olmadığından mümkün olduğu kadar dikey çizgilerden kaçınılmıştır. Boydan boya uzun yırtıkları önlemek amacı ile desen sınırındaki basamaklar halinde yükselen, köşeli ve daha çok enine desenler tercih edilerek, aynı doğrultuda uzanan uzun yırtıklar yerine, yalnızca küçük deliklerin meydana gelmesi sağlanarak yapılmıştır. Siyah, Koyu Kırmızı (Bordo), Lacivert, Koyu kahve, Açık kahve, Pembe, Turuncu, Sarı, Krem ve Beyaz renkleri kullanılmıştır. Bezayağı tekniğinde, kök boya ile boyanmış, eriş (yün) dokuma.

\section{Pomak Köylerindeki Dokumalar}

Pomak dokumaları, esasen köy içinde yaşayan insanların şahsi eşyaları olarak bilinir. Öneklerde ise perde, örtü, yaygı, battaniye, yastık, yorgan, yatak 
yüzü çoğunlukta yer almaktadır. Dokumalar, köylerde evlerin kullanılmayan bölümlerine kaldırılmış veya ambar kapaklarına örtü olmuş, çoğunluğu da çürümeye bırakılmış.

Kırklareli'ne bağlı Vize-Soğucak köyünde, Pomak dokumaları ile ilgili olarak yapmış olduğum araştırma sonucunda köyde dokuma işleri ile uğraşanların var olduğunu gördüm. Ancak köyde sadece yaşlılar dokuma işi ile uğraşmakta ve genç kesimin çoğunluğu büyük şehirlere göç etmiş olduğundan dokuma ile uğraşan kişilerin sayısı gün geçtikçe azalmakta. Son kalan keçi ve koyunlara yarenlik etmek de yine yaşlılara kalmıştır.

Soğucak köyünde bundan 40 yıl öncesine kadar misır kabukları kullanılarak hasır dokumalar yapılmıştır. Günümüzde ise yapılmamasına rağmen daha önceden dokunan örneklerine de evlerde rastlanılmaktadır. ${ }^{5}$

\subsection{Pomak Köylerindeki Dokumalarda Malzeme ve Yöntemler}

Balkan köylerinde kış mevsiminin çetin geçmesinden dolayı keçi kılından yapılan dokumalar battaniye (çergi) olarak kullanılmaktadır. Bezayağı dokuma tekniği ile dokunmuşlardır. Çergilerinin çözgüleri siyah olup, atkıları beyaz keçi kıllarının rengârenk doğal kök boyaları ile boyanarak dokunmaktadır. Sert tutumlu olduklarından kaşındırmaktadırlar. Sarı, pembe, kırmızı, yeşil ve siyah gibi can alıcı parlak renkler tercih edilmektedir.

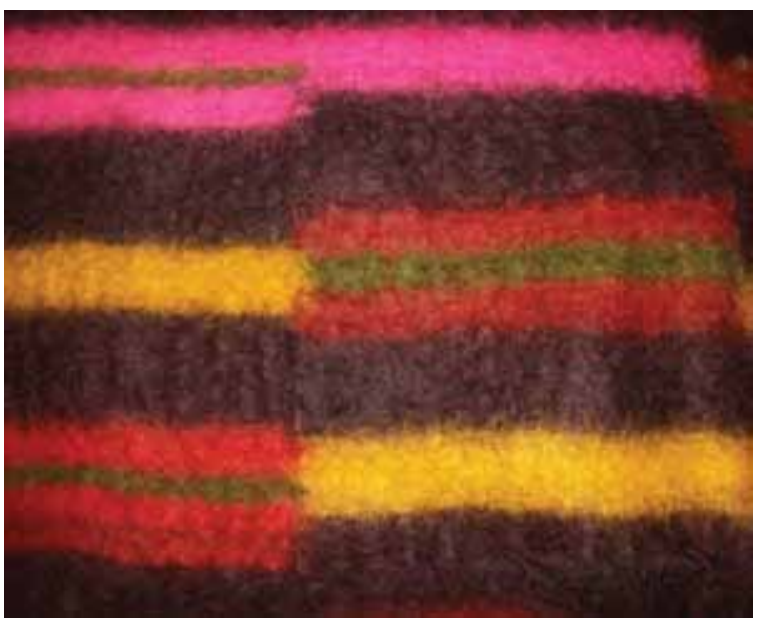

Foto 12. Soğucak Köyü. 13.07.2010. Keçi kılı kullanılarak yapılmış battaniyenin yakın görünüşü

Tülü dokumalar genellikle keçi kılı kullanılarak bezayağı tekniğinde yapılmıştır. Dokuma işlemi yapılırken tezgâh üzerine sopaya 20 tel sarı, 20 tel siyah, 20tel kırmızı, 20 tel koyu parlak mavi, 20 tel parlak

Hatice Bener'in 20.01.2010 tarihinde şifahen verdiğgi bilgilere göre pembe ip dolandıktan sonra sopa çıkarılırdı. Üst sırasına 5 ile 10 kadar bezayağı dokunur. Daha sonra bu işlem 3 sıra daha tekrar edilip renkler kaydırılarak dokuma işlemine devam edilirdi. Böylece peluş özelliğinde tülü ve damalı görüntü elde edilmiş olunurdu. ${ }^{6}$

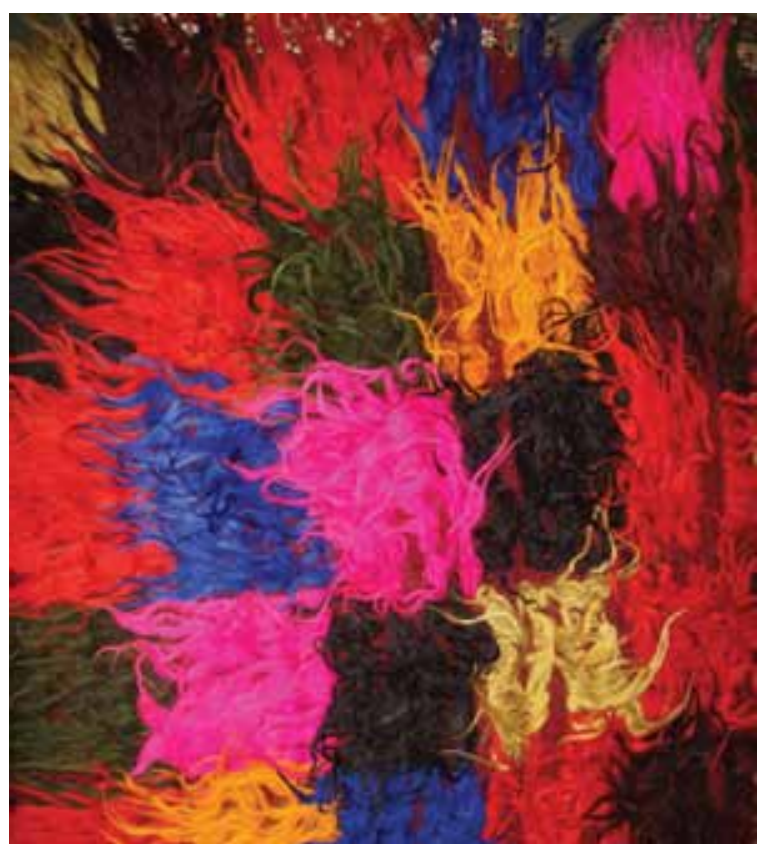

Foto 13. Soğucak Köyü.13.07.2010. Damalı Tülü dokuma örneği ön görünüşü.

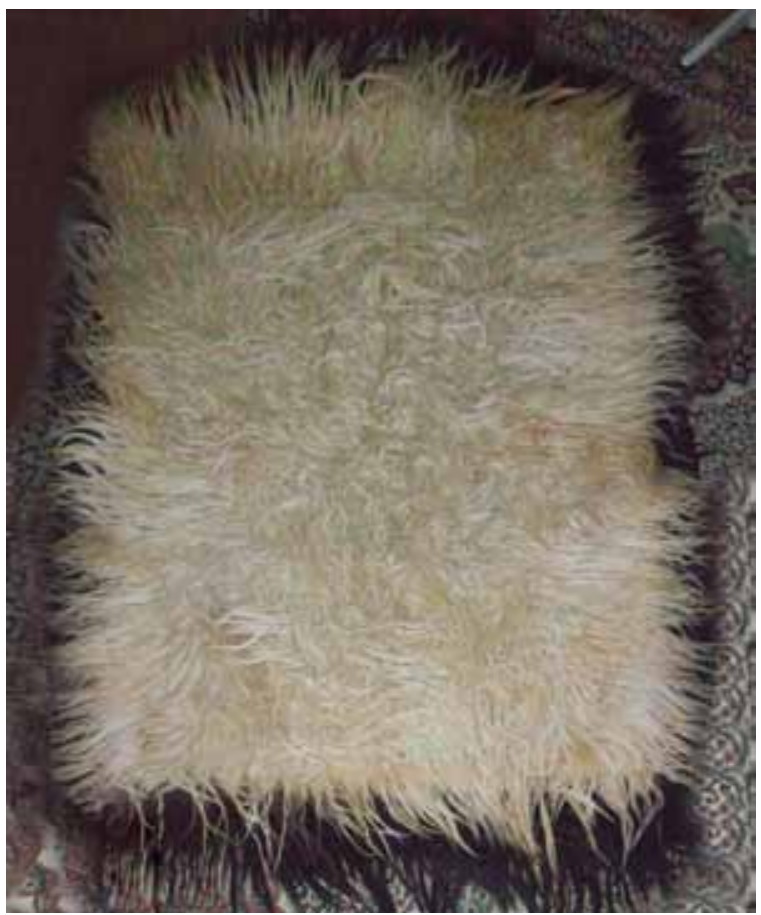

Foto 14. Fatma Atay'a ait. 20.01.2010. Keçi kılından yapılmış Tülü dokuma.(ön yüzü)

6 Fatma Atay'ın 20.01.2010 tarihinde şifahen verdiği bilgilere göre 


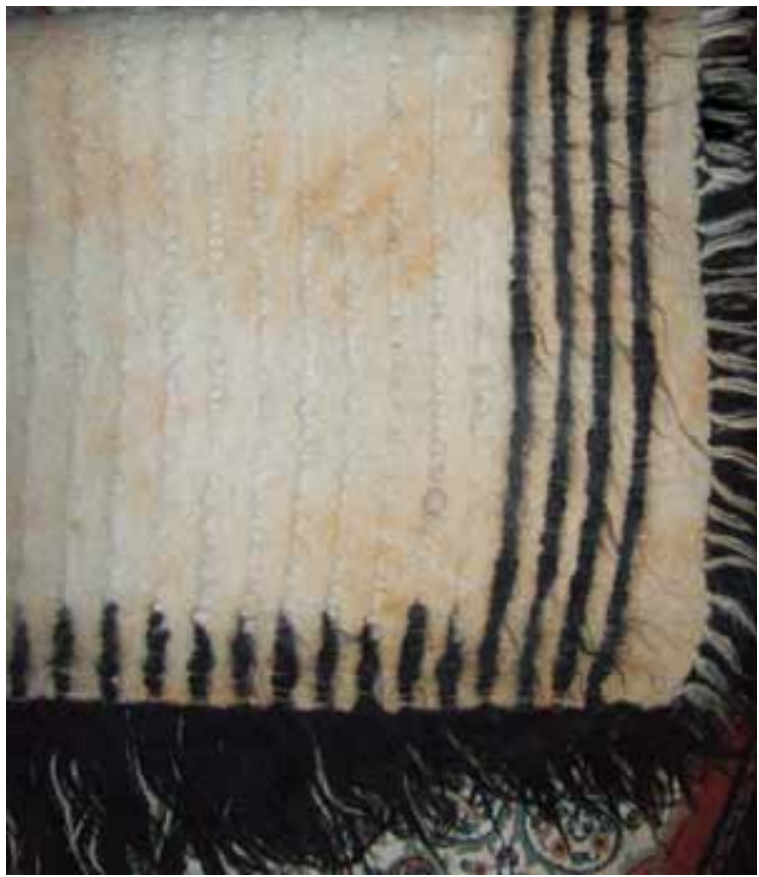

Foto 14a. Fatma Atay'a ait. 20.01.2010. Keçi kılından yapılmış Tülü dokumanın arka yüzünden görünüş.

Çizgili Kilimler bezayağı tekniği ile dokunmuşlardır. Atkı ve çözgü de eriş (yün) iplikler kullanılmaktadır. Koyu ve canlı renklerle dokunan kilimlerde genelde çözgü ipliği siyah renktir. Dokuma eni $70 \mathrm{~cm}$ ile 1 metre arasında değişmektedir. Birleştirmeler sonradan el ile yapılmıştır. Sarı, kırmızı, mavi aralarına siyah renkli iplik kullanarak oldukça canlı renklerde dokunan kilimler göz alıcıdır. ${ }^{7}$

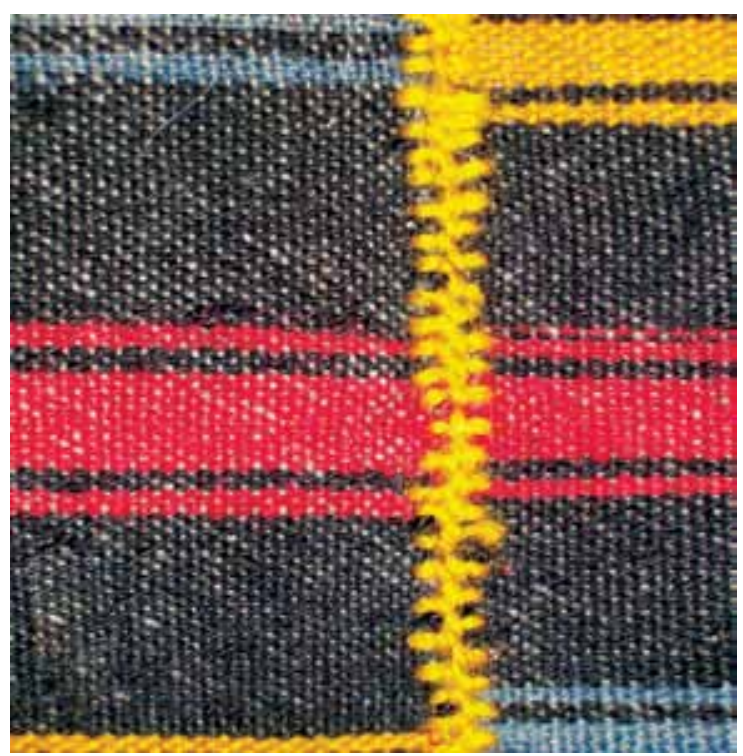

Foto 15. Fatma Çanta Soğucak Köyü. 13.07.2010. Çizgili Kilim birleştirilmesi yakın görünüşü

Fatma Çanta'nın 13.07.2010 tarihinde şifahen verdiği bilgilere göre
Çizgili Kilimler bezayağı tekniği ile dokunmuşlardır. Atkı ve çözgü de eriş (yün) kullanılmaktadır. Koyu ve canlı renklerle dokunan kilimlerde genelde çözgü ipliği siyah kullanılmıştır. Dokuma eni $70 \mathrm{~cm}$ ile 1 metre arasında değişmektedir. Birleştirmeler sonradan el ile yapılmıştır. Sarı, kırmızı, mavi aralarına siyah renkli iplik kullanarak oldukça canlı renklerde dokunan kilimler göz alıcıdır.

Pala Kilimler bezayağı tekniği ile dokunmuşlardır. Çözgüde eriş (yün) atkıda ise penye iplik kullanılmıştır. Eskiyen penye tişörtler kesilerek ip olarak değerlendirilmektedir. Koyu ve canlı renklerle dokunan kilimlerde genelde çözgü ipliği siyah renktir. Sarı, kırmızı, mavi gibi renklerle dokunmasına rağmen aralarına atılan beyaz iplikler, çözgününde beyaz renkli iplikle hazırlanmasından dolayı pastel bir görünüm sağlamaktadır. Dokuma eni $70 \mathrm{~cm}$ ile 1 metre arasında değişmektedir. ${ }^{8}$

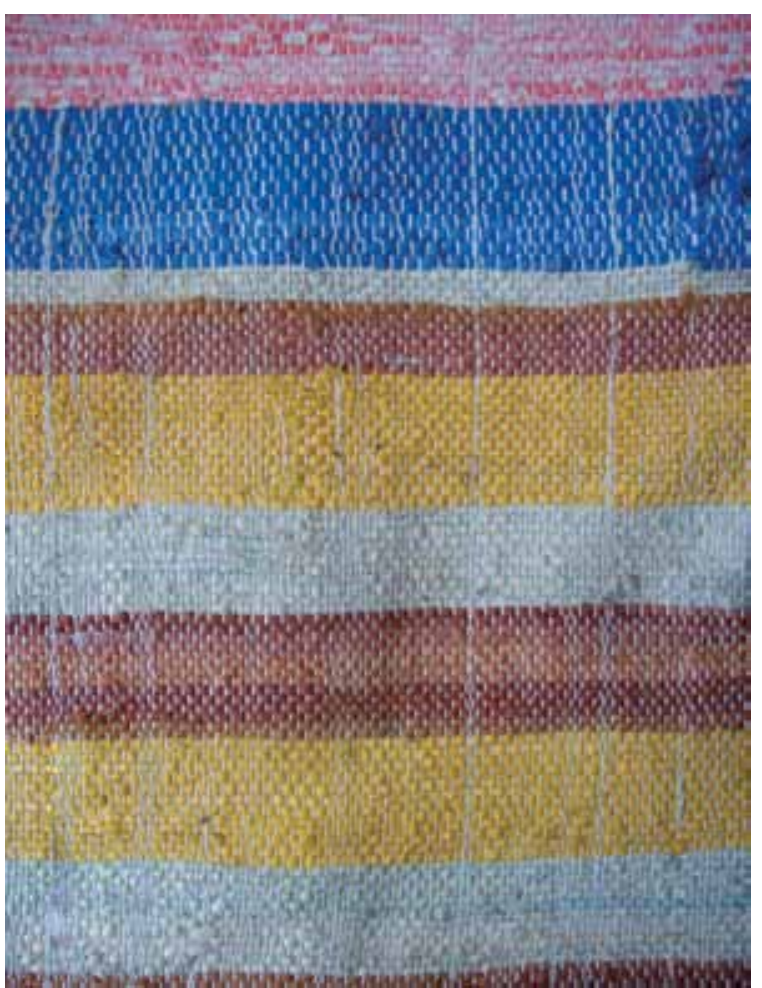

Foto 16. Fatma Çanta Soğucak Köyü .13.07.2010. Pala Kilim

Pala Kilimler bezayağı tekniği ile dokunmuşlardır. Çözgüde eriş atkıda ise penye iplik kullanılmıştır. Eskiyen penye tişörtler kesilerek ip olarak değerlendirilmektedir. Koyu ve canlı renklerle dokunan kilimlerde genelde çözgü ipliği siyah kullanılmıştır Sarı, kırmızı, mavi aralarına siyah renkli iplik kullanarak oldukça canlı renklerde dokunan kilimler göz alıcıdır. Yukarıdaki fotoğrafta ise çözgüler beyaz olarak

8 Fatma Çanta'nın 13.07.2010 tarihinde şifahen verdiği bilgilere göre 
hazırlanmıştır. Sarı, kırmızı, mavi gibi renklerle dokunmasına rağmen aralarına atılan beyaz ipler ve çözgününde beyaz hazırlanmasından dolayı pastel bir görünüm sağlamaktadır. Dokuma eni $70 \mathrm{~cm}$ ile 1 metre arasında değişmektedir.

Çergeler ve yorgan yüzleri iki gücü ve iki ayaklı tezgâh kullanıldığından, sadece bezayağı tipinde dokumalar elde edilmektedir. Üretilen dokumalar daha çok yaygı ve çeşitli yerlerde süsleyici unsur olarak örtü niteliğinde değerlendirilmektedir. Kullanım yerine uygun ölçülerde üretilen dokumalar, çoğunlukla sarı, kırmızı, pembe, siyah ve bunun gibi canlı renklerle, yatay-dikey çizgili ve ekose desenli olarak üretilmektedir. $50 \mathrm{~cm}$ dokunan iki kumaş sonradan ortadan el ile birleştirilmektedir. ${ }^{9}$

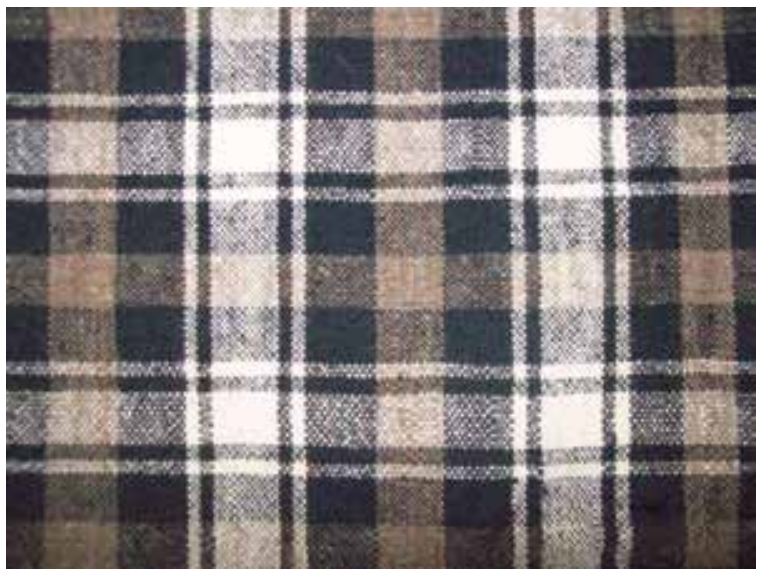

Foto 17. Fatma Atay .20.01.2010. Bezayağı tekniğinde, kök boya ile boyanmış ekose desenli eriş (yün)çerge dokuma

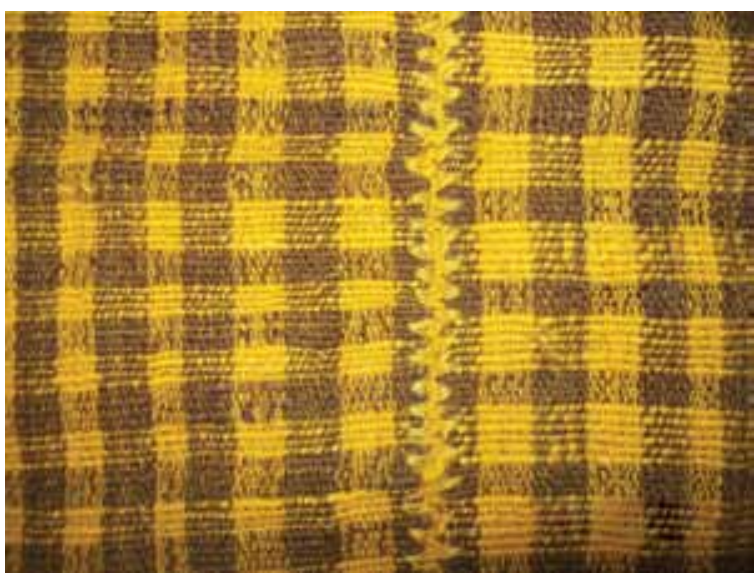

Foto 18. Nuri Yaman'a ait .12.01.2010. Ekose Desenli Dokuma

Bezayağı tekniğinde, kök boya boyanmış, çözgüde 12 ip sarı, 14 ip kahve, atkıda 6 ip sarı, 4 ip kahve eriş (yün) iplikle $50 \mathrm{~cm}$ eninde ve 3 metre boyunda dokunan iki kumaş sonradan ortadan el ile birleştirilerek yorgan yüzü olarak kullanılmıştır. İki gücü ve iki ayaklı tezgâh kullanıldığından, sadece bezayağı

9 Fatma Atay'ın 20.01.2010 tarihinde şifahen verdiği bilgilere göre tipinde dokumalar elde edilmektedir. Üretilen dokumalar daha çok yaygı ve çeşitli yerlerde süsleyici unsur olarak örtü niteliğinde değerlendirilmektedir. Kullanım yerine uygun ölçülerde üretilen dokumalar, çoğunlukla sarı, kırmızı, pembe, siyah ve bunun gibi canlı renklerle, yatay-dikey çizgili ve ekose desenli olarak üretilmektedirler.

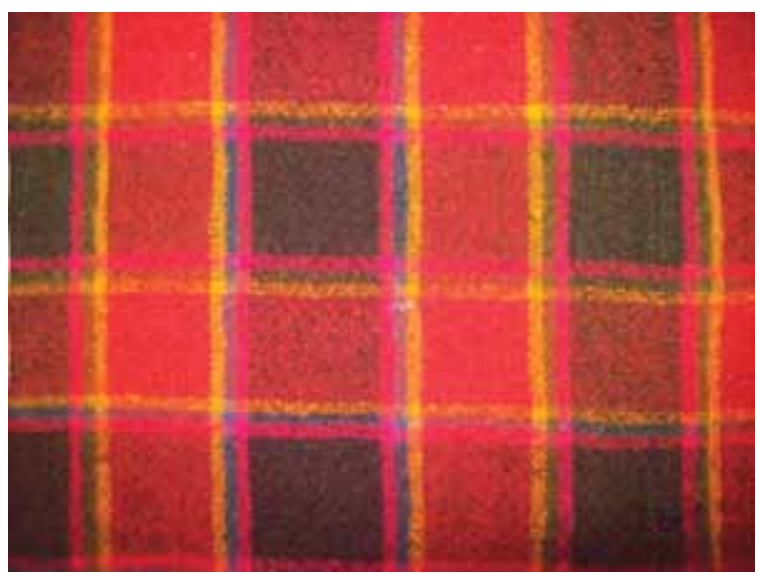

Foto 19. Fatma Atay'a ait. 20.01.2010. Bezayă̆1 tekniğinde, kök boya ile sarı, pembe, lacivert ve mavi renklerde boyanmış eriş (yün) iplikli ekose desenli dokuma.

Geometrik desenli Kilimler eskiden dokunmasına rağmen günümüzde pek dokunmamaktadır.

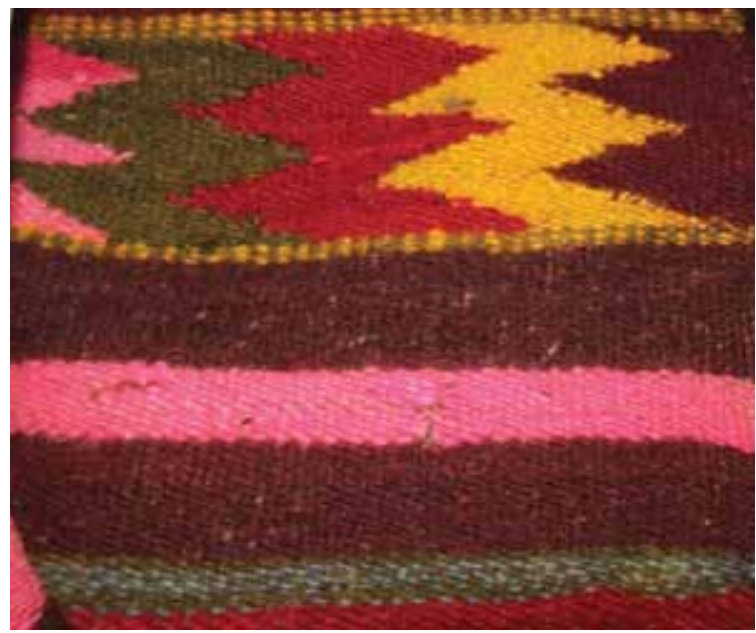

Foto 20. Soğucak Köyü. 13.07.2010. Geometrik - Çizgi desenli kilim dokuma

Kırklareli çevresi Pomak köylerinde üretilen el dokumaları; hammaddelerine, boyutlarına, tiplerine, örgü tekniklerine, renk ve desenlerine göre çeşitlenmekte ve bu özellikler doğrultusunda kullanım alanı bulmaktadırlar.

Pomak el dokumalarının kullanılan hammadde yönü incelendiğinde, eski örneklerinde kıl ve yün (eriş) ipliğinin yoğun şekilde kullanıldığı anlaşılmaktadır.

Pomaklar'ın özellikle elbiselik kumaşlar, çeşitli örtü ve yer yaygılarında eriş kullandıkları dikkat çek- 
mektedir. Yün tarandıktan sonra eğirme işleminde kullanılan araca Pomakça "furka" denilmektedir. Yörede eriş çözgü üzerine keçi kılıyla yapılan dokumalar, sıcak tutması yüzünden genellikle "kepenek" ve "yer yaygısı" olarak kullanılmaktadır.

Kilimlerde çözgüler genellikle siyah eriş ipliklerden hazırlanmaktadır. Şayet açık renkli ipliklerle dokuma yapılacak ise çözgülerde beyaz eriş (yün) iplik tercih edilmiştir. Kullanılan renkler; Sarı, pembe, kırmızı, mavi, yeşil ve siyahtır.

Pomak el dokumalarının desenli, desensiz, boyuna çizgili, enine çizgili ve ekose desenli olarak dokunmuşlardır. Dokumalarda bezayağı ve dimi örgü tekniği uygulanmıştır.

Boyuna çizgili desenler aynı genişlikteki dikey çizgilerin belli aralıklarla yan yana sıralanmasından oluşan desenler olabildiği gibi; farklı genişlikteki dikey çizgilerin belli aralıklarla yan yana sıralanmasından oluşturulanlarına da rastlanmaktadır.

Yatay çizgili desenler aynı veya farklı genişlikteki yatay çizgilerin belli aralıklarla üst üste sıralanması ile elde edilmektedir.

Pomak dokumalarında ekose desenler, belirli bir düzende hazırlanan renkli çözgü iplikleri üzerine, yine belli renk düzeni içinde atkı ipliklerinin sıralanması ile oluşturulmaktadır. Çözgüde karışık, atkıda ise basit renk düzenlemesi yapılarak birçok değişik görünüm elde edilebilir. Ekose desenli kumaşlar genellikle yer yaygısı, yastık, sofra bezi, heybe, önlük, yatak ve yüklük örtüsü vb. yerlerde kullanılmaktadır. ${ }^{10}$

\subsection{Pomak Köylerindeki Dokumalar}

Pomak el dokumalarının enleri 50 ile 100 cm arasında yapılmaktadır. Dokumaların boyları ise istenilen ürünün kullanım yeri ve özelliğine göre değişebilmektedir. Yatak örtüsü gibi geniş yüzeyler gerektiren ürünler, aynı uzunluktaki dokumaların yan yana elde dikilmesiyle oluşturulmaktadır. Böylece geniş örtüler, ortadan dikişli olarak hazırlanmaktadır. Dokuma ipliklerinde hammadde olarak keçi kılı ve eriş (yün) kullanılmıştır. Dokumaların en ağırlıklı renkleri sarı, kırmızı mavi ve pembedir. Bunların dışında mor, mavi, yeşil, sarı, bordo, kahverengi, siyah, beyaz ve lacivert gibi renklerde yapılan dokumalara da rastlanmaktadir.

Son yıllarda Pomak dokumaları genellikle yaşlılar tarafından sadece kendi ihtiyaçlarını karşılamak üzere dokunmaktadır. Köylerden büyük şehirlere gençlerin gitmesi, köyde kalanların dokuma işine önem göstermemesi ve değişen yaşam koşulları nedeniyle Pomak dokumaları kaybolma tehlikesi yaşamaktadır.

10 Fatma Atay'ın 20.01.2010 tarihinde şifahen verdiği bilgilere göre ve http://pomakkulturu.blogspot.com/2007/04/pomak-eldokumalar.html (2010)

\section{Poyralı Köyü Dokumaları}

Poyralı Köyü Dokumaları'nın üretildiği yer, Kırklareli ilimiz Pınarhisar İlçesi'ne bağlı Poyralı Köyü'dür. Poyralı Köyü, bağlı bulunduğu Pınarhisar İlçesi'ne 6 Km. Kırklareli Merkez'e 36 km. mesafededir. Istranca Dağları eteklerinde kurulmuştur. Poyralı Köyünde yaşayanların ataları 1363 yılından itibaren Osmanlılar tarafından Balkanlarda alınan yerlere Anadolu'dan getirilip yerleştirilen Türklerdir. 1877-78 OsmanlıRus Savaşı sırasında Balkanlardan Anadolu'ya başlayan tersine göçlerle Bulgaristan Plevne'ye bağl Lofça Kazasından 60 hane olarak öküz arabaları ile yola çıkan ve 1891 yılında bugünkü Poyralı Köyüne ulaşan insanlardır. Köyün ilk kuruluşu sırasında bu yörede yapılan at ve öküz arabalarının poyralarının bu köyün içinden geçen derenin kenarında bulunan karaağaçlardan yapılması ve bu poyra yapımının çevrede tanınması buranın adının Poyralı olarak adlandırılmasını sağlamıştır.

\subsection{Poyralı Köyündeki Dokumalarda Malzeme ve Yöntemler}

Dokumaya başlamadan önce çözgü ipleri hazırlanır. Çözgü, atkı ve desen ipleri, 1965-70'li yıllara kadar köyde beslenen koyunların yünlerinden elde edilirken, günümüzde Pınarhisar İlçesinde bulunan bir yüncü esnafından satın alınır. Bahçede daire yapacak şekilde yere çakılan kazıkların etrafından dolanarak çözgüler hazırlanır. Çözgü genellikle 20-22 uzunluğunda, 2 kg. eriş ipliğinden hazırlanır. Köyde çözgü iplikleri "krosna" denilen sargı levendine sarılır ve krosna tezgâha yerleştirilerek önce 2 adet gücüden, sonra da taraktan geçirilerek yine adına "krosna" denilen sargı levendine sarılır. Böylece dokumaya başlama safhasına gelinmiş olur. Çözgü ipliklerinin gücülerden ve taraktan geçirilmesi belli bir düzen içinde yapılmaktadır.

Poyralı Köyü dokumalarında eriş (yün) denilen çözgü ipi siyahtır. Atkı ve desen iplerinde beyaz, kırmızı, sarı, yeşil, mavi, krem, mor, siyah ve ana renklerin açık ve koyu tonları kullanılmaktadır. Çözgüde siyah rengin tercih edilmesi, üzerine pek çok rengin uyumlu olarak kullanılabilecek olmasıdır.

Dokuma tezgâhı köyün erkekleri tarafından köyde kolay bulunan meşe, kavak gibi ağaçlardan yapılır. Taraklar İstanbul'dan satın alınmaktadır.

\subsection{Poyralı Köyü Dokuma Tezgâh Parçaları}

Krosna; Dokuma için hazırlanan çözgü iplerinin sarıldığı çözgü levendi ile dokunan kumaşın sarıldığı sargı levendine denir. Uzunluğu tezgâhın eni kadar, kalınlığı da 10-12 cm çapında silindir şeklinde iki adet ahşap parçadır. Birer uçları dört yüzlü hale getirilmiş, her bir yüzünde bir delik açılmıştır. Bu deliklere çözgü krosnasında çözgüyü germek ve salmak 
için gergi sopası, sargı krosnasında da dokunan kumaşı sarmak için yan sopa sokulur. Böylece dokunmaya hazır çözgü ipleri ile dokunan kumaşın gergin durması sağlanmış olur.

Gücü; Çözgü levendinden (Krosna) gelen ipliklerin birinin altta diğerinin üstte kalarak ağızlık yapmasını ve bu ağızlıktan içinde atkı ipliği bulunan mekiğin kolayca ve hızlı bir biçimde geçirilmesini sağlayan parçalardır. Ağızlık açma işlemi bu gücülere bağlı ve dokumayı yapan kişinin ayakları altında bulunan ayaklıklar vasıtasıyla gerçekleştirilir. Uzunluğu tezgâhın eni kadar, yüksekliği $20 \mathrm{~cm}$. civarında, düzgün iki çubuğa kalın pamuk iplerinin belirli bir düzen içerisinde sarılmasıyla yapılır. Her tezgâhta 2 adet bulunur.

Makara ve Ayak; Poyralı Köyü dokuma tezgâhlarında, tezgâhın kirişine enine konulan bir ağaç çubuğa bağlanmış 2 adet makara ve bir ucu gücüye diğer ucu ayağa bağlanmış 2 adet ayak bulunmaktadır. Bir ucu ayağa, bir ucu gücüye bağlanmış ip bu makaradan geçer. Ağızlık açmak amacıyla ayağa basıldığında, ayakla gücü arasında makara aracılığıyla bağlanan gücüler birbirinden ayrılmakta ve açılan ağızlıktan atkı geçirilerek dokuma gerçekleştirilmektedir.

Tefe ve Tarak; Tefe ve tarak bir bütün oluşturmaktadır. Gücülerden geçen çözgü ipleri taraktan da geçirilmiş, tefe iki yandan da tezgâhın üst kirişine monte edilmektedir. Gücülere bağlı ayaklardan birine basılmasıyla gücülerin önünde açılan ağızlıktan, içinde masuraya sarılı atkı ipinin bulunduğu mekik atılır, mekik karşı kenardan çıktığı gibi içinde tarak bulunan tefe, dokuyan kişi tarafından kendine doğru çekilerek atkı ipinin dokunan kumaşa sıkıştırılması sağlanır. 1965-70'li yıllara kadar kemikten köyde yapılan tarakların yerini, daha sonraları İstanbul'dan fabrikalardan çıkma demir taraklar almıştır.

Çımbar; Dokunan kumaşın sol kenarından sağ kenarına doğru gergin durmasını sağlayan, iki adet demir çubuktur. Bu demir çubukların kenar uçları tırnaklı, ortaları pantolon kemeri gibi delikli, diğer uçları ise deliklere girmeye uygun tek tırnaklı olarak yapılmışlardır. Dokumanın enine göre kısalıp uzamaya müsaittirler.

Mekik ve Masura; Mekik, içinde atkı ipliğinin sarılı olduğu masurayı barındıran bir dokuma tezgâhı parçasıdır. Ahşaptan dikdörtgen prizması şeklinde olup köyde yapılabilmektedir. Mekiğin içerisinde atkı ipinin sarılı olduğu bir parça daha bulunur ki, buna masura denir. Masura 1970'li yıllara kadar köyde çokça yetişen, içi boş olan ve adına "Baldıran" denen dere sazlarına benzeyen bir bitkiden yapılırken, günümüzde içi boş plastik elektrik borularından yapılmaktadır. Mekik ve masuranın dokuma içerisin- deki görevi, atkı ipliğini çözgü iplerinin arasından bir sağa, bir sola geçirerek dokumanın gerçekleşmesini sağlanmaktır.

Yan Sopa ve Gergi Sopaları; Yan sopa; bir ucu çözgü iplerinin sarılı olduğu çözgü levendinin (krosna) bir kenarında bulunan deliğe girmiş, diğer ucu ise dokuyan kişinin elinin altına kadar uzanmış inceuzun bir sopadır. Dokuma yapıldıkça çözgü levendindeki (krosna) çözgünün salınması görevini üstlenmiştir. Gergi sopası ise; sargı levendinin (krosna) bir kenarında bulunan deliklere sokulmuş olup, dokuma ilerledikçe dokunan kumaşın sarılması görevini yerine getirmektedir.

Tezgâh ve Dokuma özellikleri; Yatay olan Poyralı Köyü dokuma tezgâhının uzunluğu 2,30 metre genişliği 1.30 metre dokumanın yapıldığı çözgü ve sargı leventleri (krosna) seviyesi yerden 20-40 santimetre ve tezgâhın zeminden en yüksek seviyeyi oluşturan tefenin üst seviyesine kadar olan mesafe de 1.30 metre civarındadır. Bu ölçülere sahip bir tezgâhta 1 metreye kadar genişlikte dokuma yapılabilmektedir. Dokunan ürünün kesilip alınabilmesi için en az $75 \mathrm{~cm}$. kadar dokuma işlemi yapılıp sargı levendine (krosna) sarılması gerekmektedir.

Poyralı Köyü dokumacığında kilimlerde bezayağı dokumalarda ki atkı ipliği çözgü sisteminden ayrıca renkli desen ipliklerinin geçirilmesi ile yapılan bir dokuma türüdür. Düz bezayağı dokuma veya atkı yüzlü dokuma zeminler üzerine ince çizgiler halinde 'sarma' işlemesini andıran bir görünüşe sahiptir. Çözgüleri desene göre belirli yerlerde aralayarak desen ipliklerini arkadan öne verir. Çözgüler arasına çoğunlukla ayrı renk ve kalınlıkta atkı ipi atılır ve tarakla sıkıştırılır. Desenin durumuna göre alınan desen ipliği dokumanın arkasından önüne geçirilerek bir çift çözgüyü atladıktan sonra tekrar arkaya geçirilerek serbest bırakılır. Tümünde değişik renkteki motifler için atlamalar yapılır, iplikler arkaya verilir ve bir sıra atkı atılıp sıkıştııılır, motiflerin durumuna göre arkadan sarkan iplikler birer çift çözgüyü atladıkta sonra geçirilip bırakılarak dokumaya devam edilir. Poyralı köyünde üretilen dokumalar cicim-zili tekniğini tanımlamasına rağmen bu adlar kullanılmamaktadır." Aynı teknikteki dokumalar Tekirdağ'ın Karacalılavuzlu köyünde de üretilmektedir. Dokunulan motifler Armut sapı, Bülbül gözü, Tahta kaldırması, Bahar dalı gibi isimlerle anılmaktadır. ${ }^{12}$

Poyralı Köyü dokumacılığı da günden güne azalmaktadır. Poyralı Köyü kadın ve kızları dokumaya istek-

11 Resmiye Gökerbüyük'ün 17.06.2010 tarihinde şifahen verdiği bilgiler ve Zekeriya Kurtulmuş'un çalışmalarından alınan bilgiler

12 Gülay Karakulak'ın 14.02.2010 tarihinde şifahen verdiği bilgiler 
li olup, dokuduklarını satabilmeleri halinde bu meziyetlerini geliştirmeye ve dokumada sürekliliğe inanmış insanlardır. O halde dokunan ürünler satılabilmelidir.

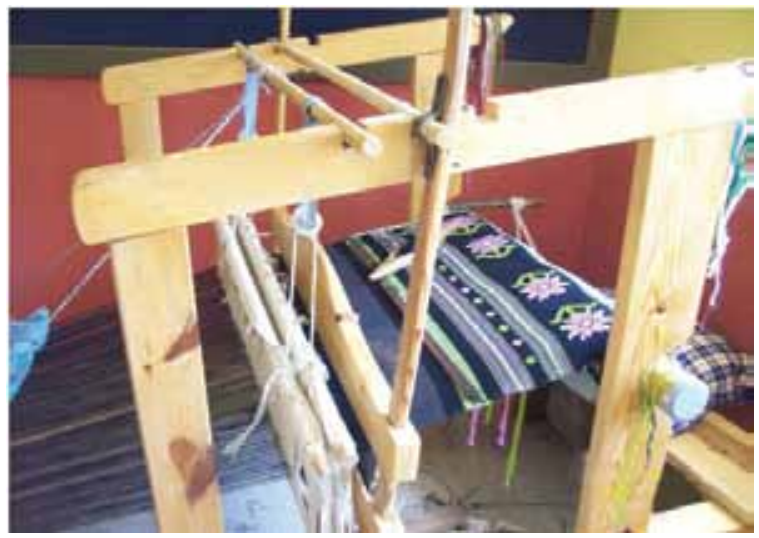

Foto 21. Poyralı Köyünden tezgâh. 17.06.2010

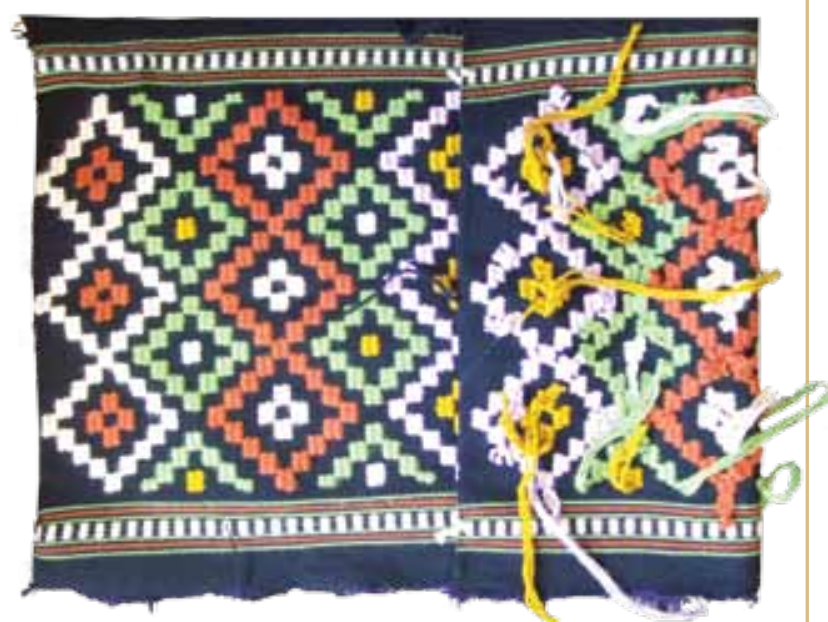

Foto 22. Poyralı Köyü'nden dokuma örneği. 17.06.2010. (ön ve arka yüzü)

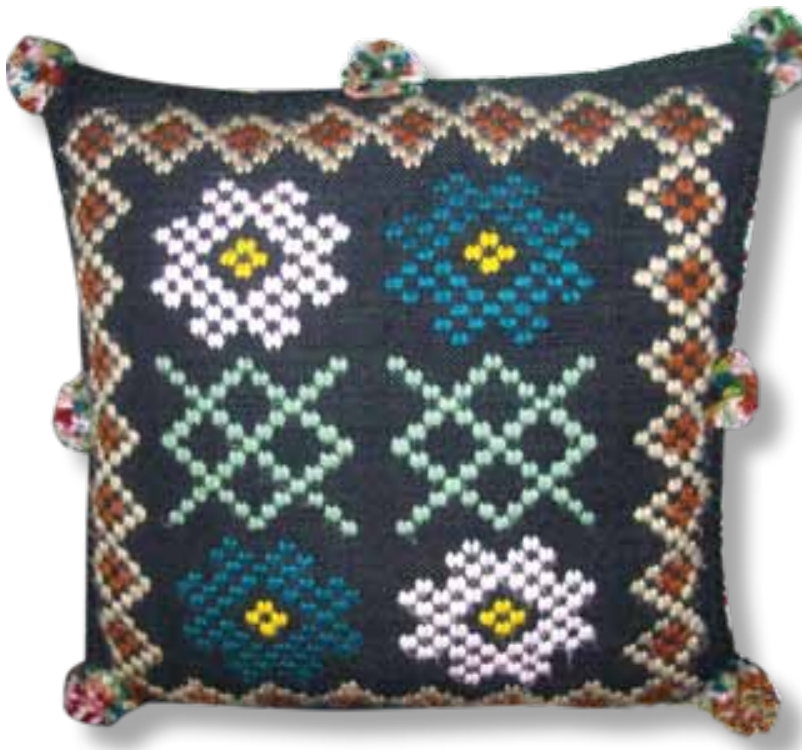

Foto 23. Resmiye Gökerbüyük'e ait. 14.02.2007. Poyralı dokumaları yastik

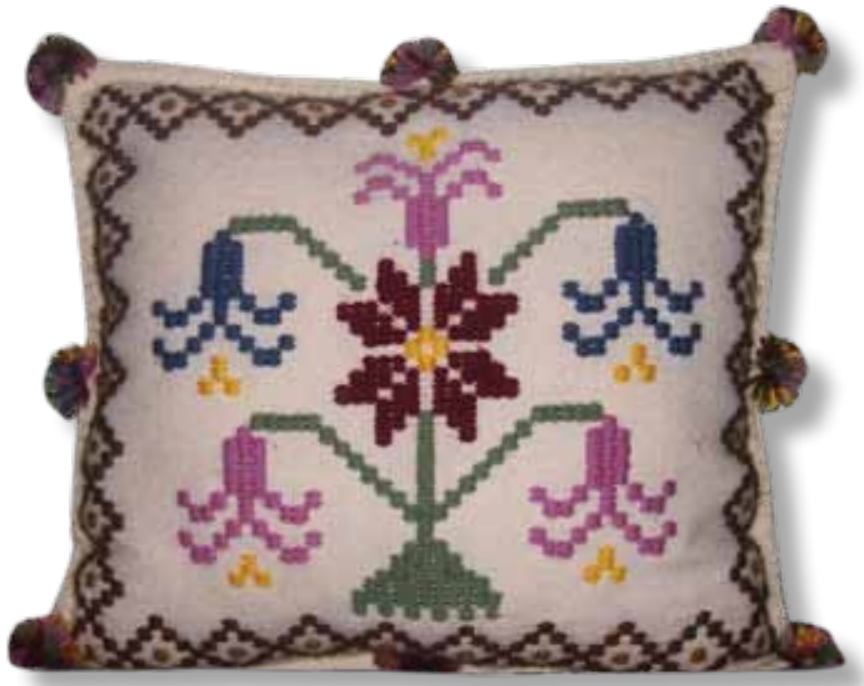

Foto 24. Resmiye Gökerbüyük'e ait. 14.02.2007. Poyralı dokumaları yastık

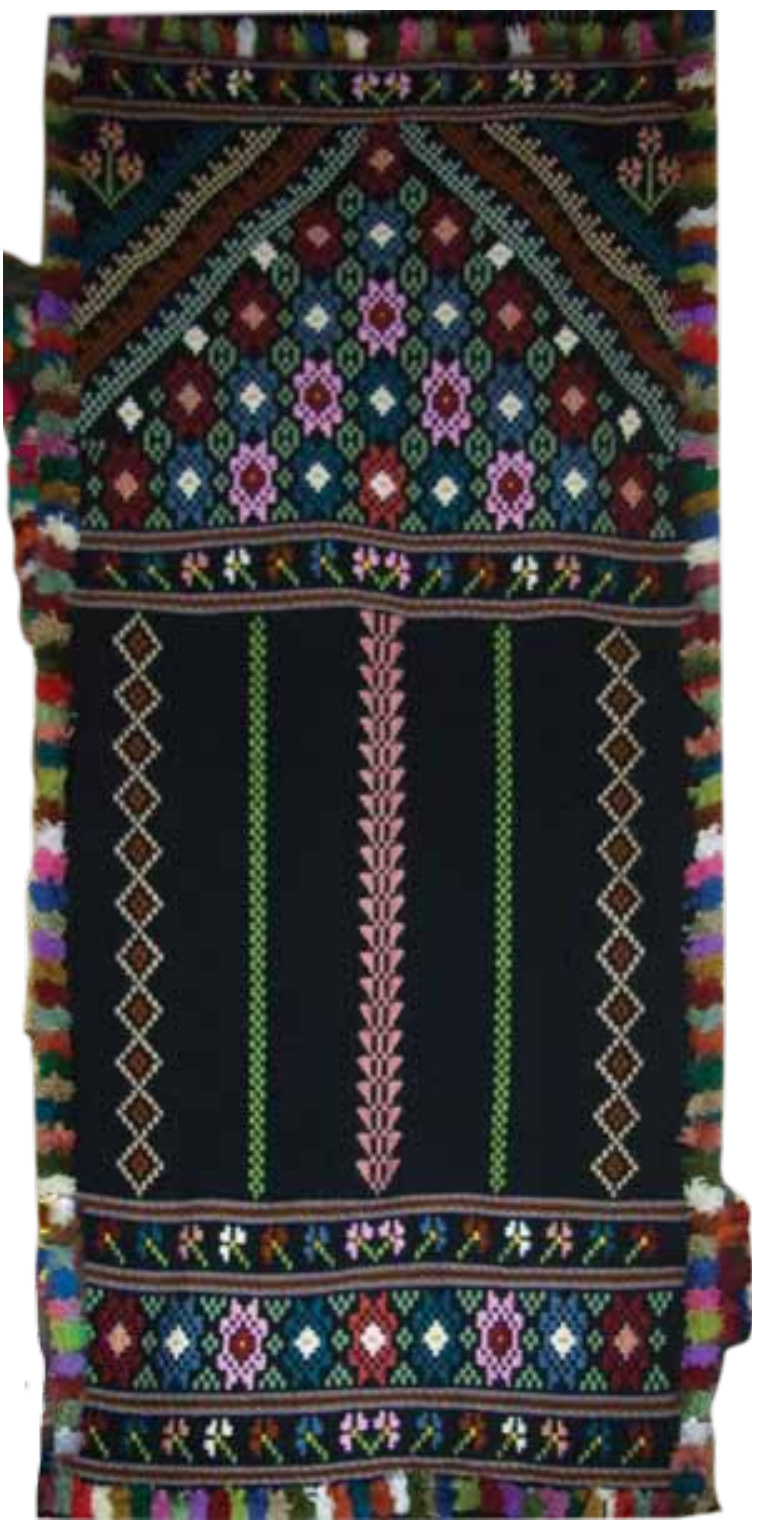

Foto 25. Resmiye Gökerbüyük'e ait. 14,02.2007.Namazlık 


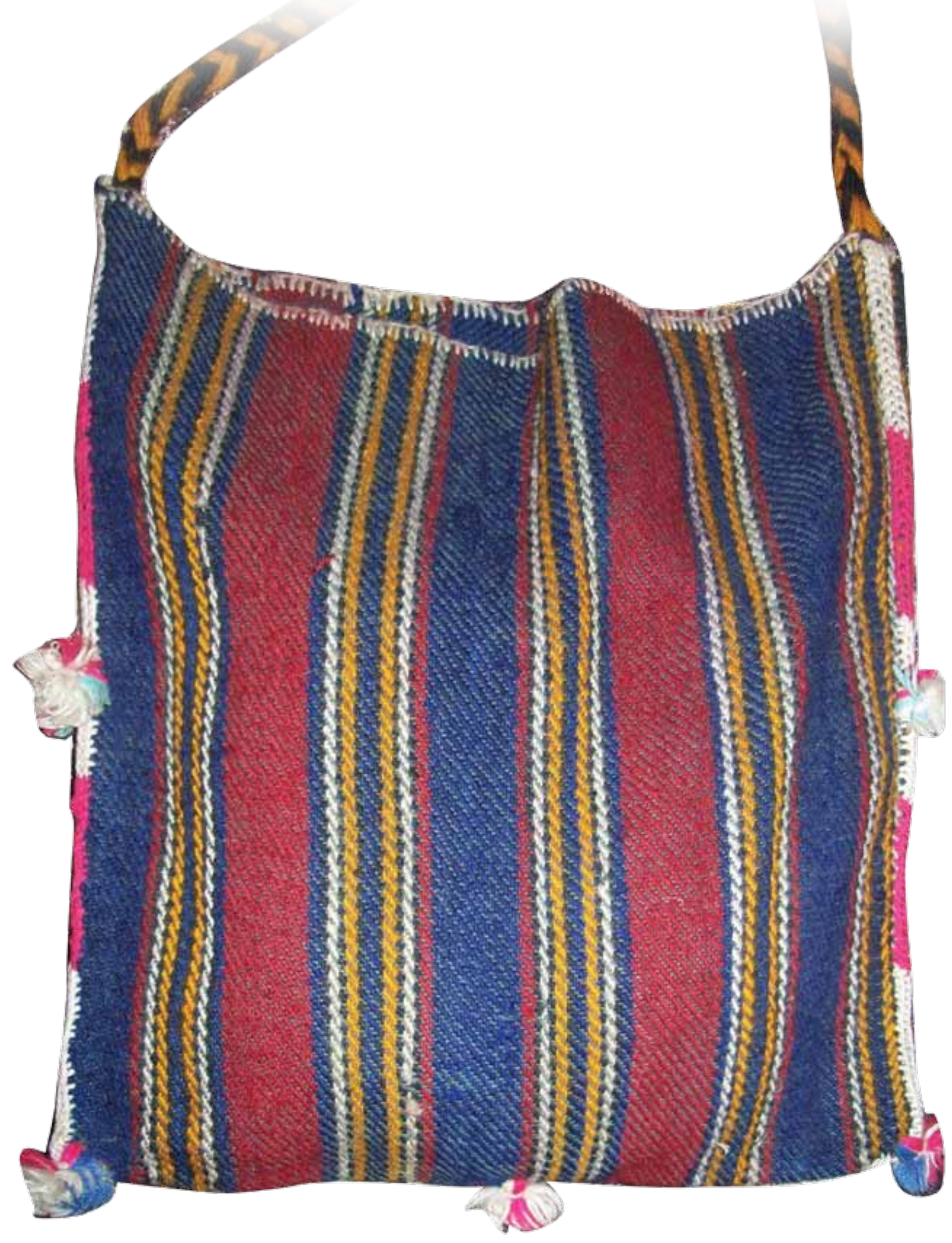

Foto 26. Mehmet Gezer'e ait. Doğum Tarihi: 1929 Poyralı Köyü. 14.02.2007. 2: 2 dimi örgü tekniğinde, kök boya ile beyaz, sarı, kırmızı, lacivert ve mavi renklerde boyanmış eriş (yün) iplikle dokunmuş heybe 


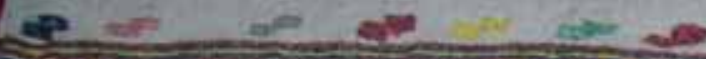

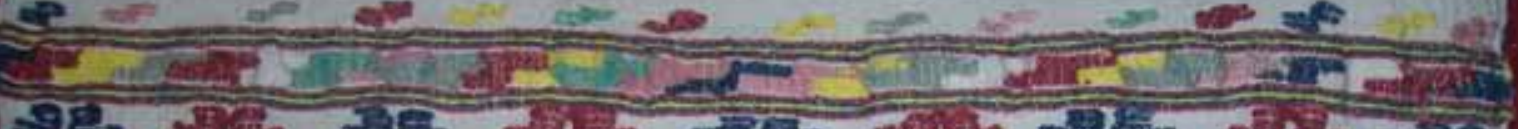

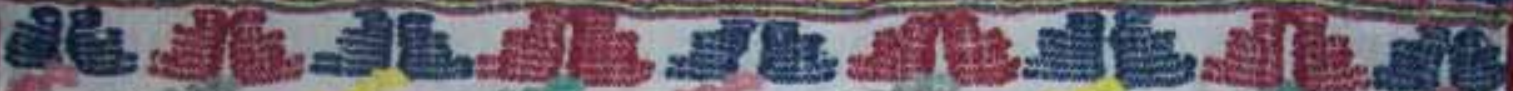
G5

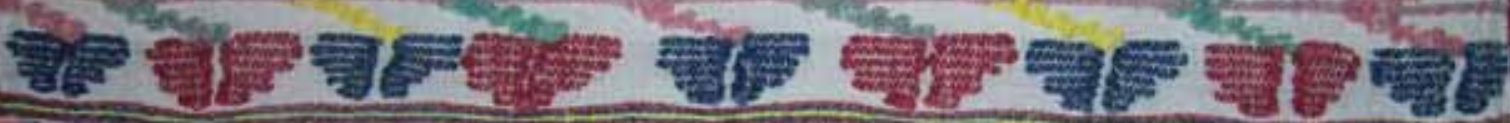

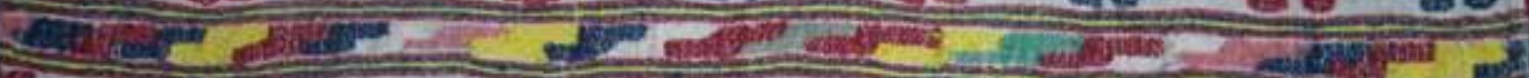
Ty-

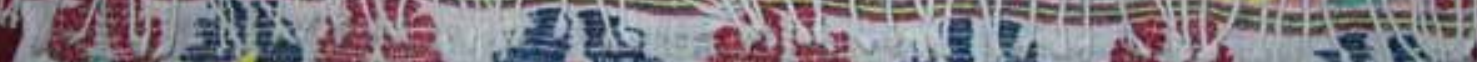

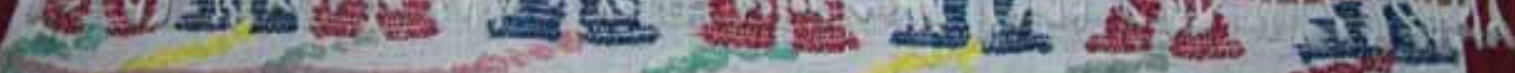

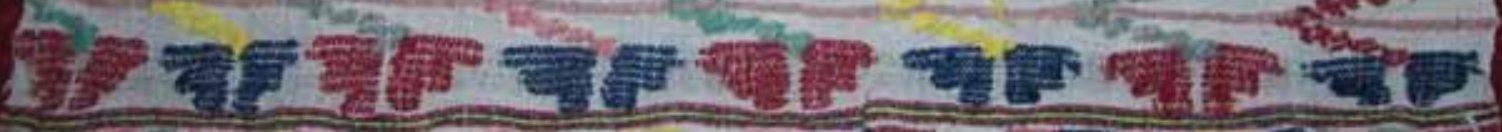

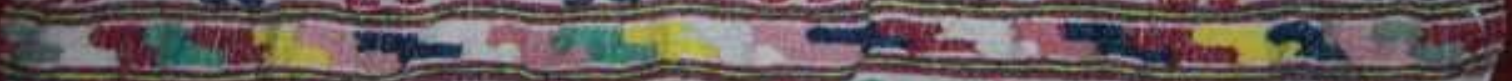

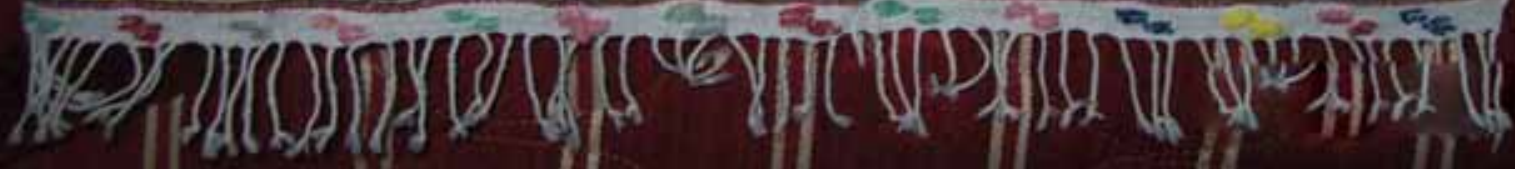

Foto 27. Mehmet Gezer'e ait. Doğum Tarihi: 1929 Poyralı Köyü. 14.02.2007. Dokuma Yağlık

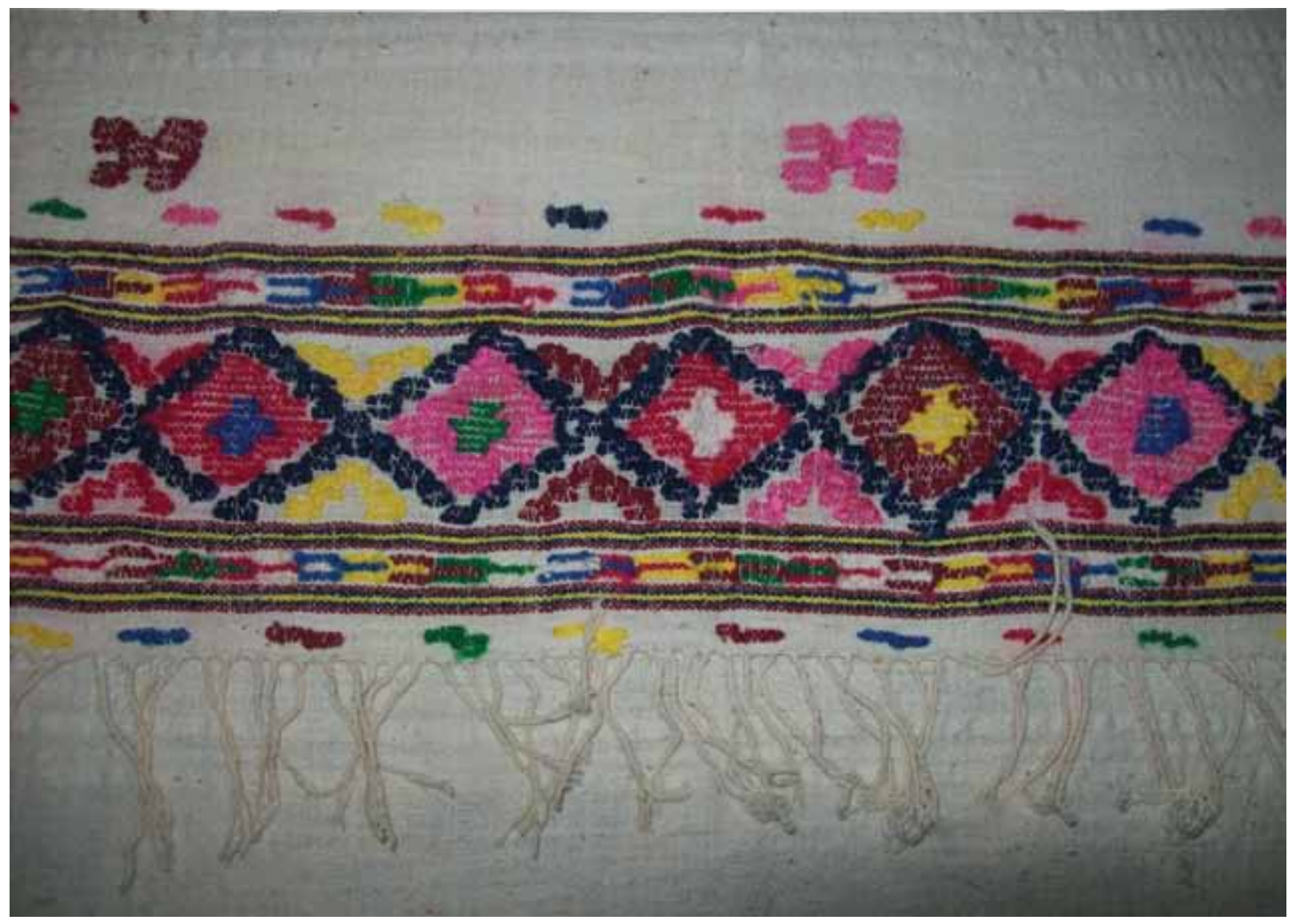




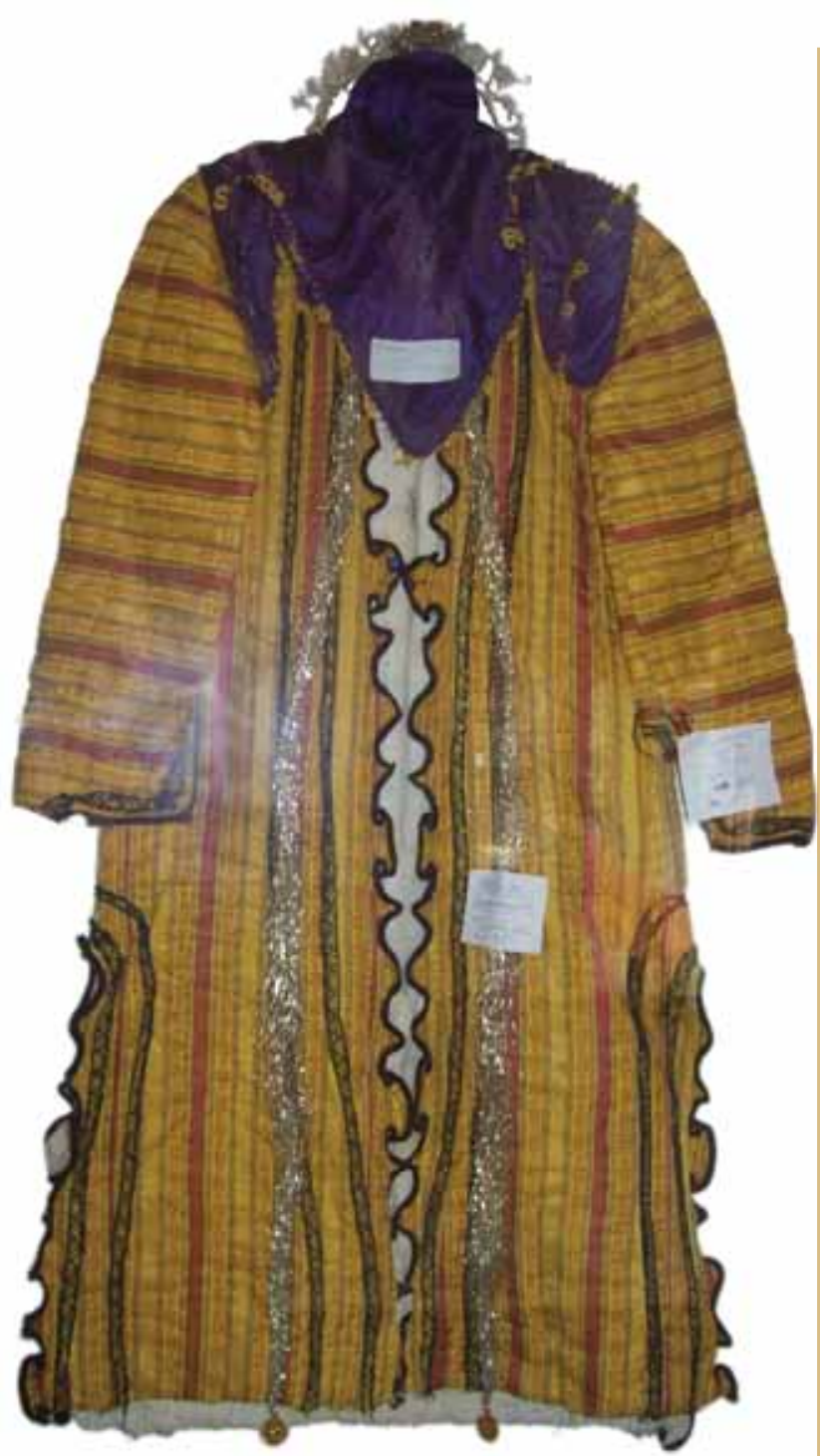

Foto 29. Nuriye Bahçıvan'ın annesi Ayşe Çolak'ın gelinliği. 14.02.2007. Poyralı Köyü Kültür evi

\section{Sonuç Olarak Trakya'daki Dokuma Tasarımlarındaki Sorunlar ve Çözüm Önerileri}

Dokuma el sanatlarımızı incelediğimizde zaman içerisinde bazılarının dokunması azalırken bazıları ise günümüzde dokunmamaktadır. Kaybolma noktasına gelen dokumalarımızın bu duruma gelmesinin nedenlerini kısaca şu şekilde açıklayabiliriz;

- Osmanlı Devleti Döneminde yaşanılan iç karışıklıklar ve savaşlar. (93 harbi),

- Anadolu'dan Balkanlara, Balkanlardan Trakya'ya tersine göçlerin yaşanması,

- Farklı toplulukların kültürel etkileşimi,

- Ekonomik- sosyolojik ve psikolojik değişimlerin yaşanması,

- Köyden kente göçlerin yaşanması,

- İnsanların sadece kendi ihtiyaçlarını veya komşularının ihtiyaçlarını karşılamak üzere dokuma işlemini gerçekleştirmeleri.

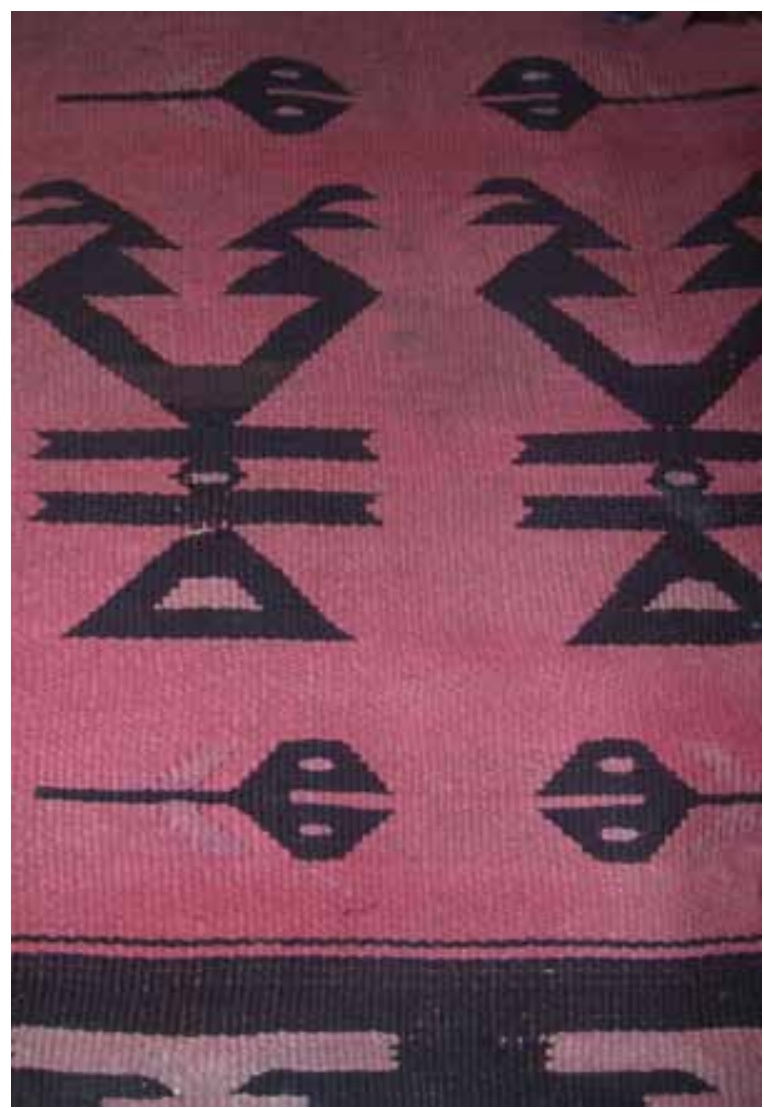

Foto 30. Poyralı Köyü Kültür Evinde 14.02.2007. Kuş motifli kilim dokuma örneği

- El dokumalarına gösterilen ilginin kaybolması,

- Kimi el sanatlarının çağlarını tamamlamaları,

- Alışkanlıkların değişmesi ve gereksinimlerin gerektiği gibi karşılanamaması,

- Teknolojinin gelişmesi ve fabrikaların kurulması.

El dokumalarında hammaddeden ürüne uzanan üretim yolunun tümüne tasarım dâhil el dokumaları ustası büyük bir özveriyle yapmaktadır. El dokuması ustası ile günümüz tasarımcısı arasında becerilerinde farklılıklar ortaya çımaktadır. Bunun nedeni bir yerde günümüz tasarımcısının deneyimi bir dokuma ustası kadar olmaması ve bunun yanı sıra bir tasarımcı kurumsal olarak el sanatçısı kadar malzemeye hâkim teknolojiye yakın olmak zorunda olduğu gibi ayrıca çağdaş duyarlılıkla işlevsellik bütünlüğünü sağlayabilmek zorundadır. Dokuma kumaşların desenlendirme olanakları gerek dokuma sırasında gerekse sonradan yapılan işlemelerle sınırsız denecek kadar fazladır. Bu nedenle ülkemizin piyasada gerçek anlamda yetiştirilmiş iyi tasarımcılara ihtiyacı vardır.

Kişinin herhangi bir üretime geçebilmesi için kültürel veya parasal bir dürtünün olması şarttır. Dokuyana gerekli desteğin ve imkânların verilmesi gerekir.

Günümüzde kültürümüzü kaybetmeden teknoloji ile birleştirerek çok güzel tasarımlar yapılabilir. Ancak firmaların çoğunda desenler yurt dışındaki 
tasarımcılardan temin edilerek firmaların desen bölümlerinde bilgisayar ortamında çalışılmaktadır. Bu da çağımızın teknolojisin de ulusumuz için büyük bir kayıptır. Oysa kendimize özgün desenler tasarlanmış olsak, kendi kültürümüzü yansıtmış ve kendi özümüze ait desenlerin kaybolmasının önüne geçmiş oluruz.

Bir koordine noktası oluşturmak, dokumalarımızdaki tasarımları kurtarmak için zorunludur. Kişinin herhangi bir üretime geçebilmesi için kültürel veya parasal bir dürtünün olması şarttır. Kişi öncelikli olarak yapacağı deseni tasarlaması gerekir. Tasarımlar bilgi ve imkânlarla sınırlıdır. Üretilen dokumalarda verimin artması için, tasarımların çizilmiş olması yapılan işin başarısında gereklidir. Bu nedenle öncelikli olarak eski dokumaların dokümanlarının yapılmış olması sonra günümüz şartlarına uyarlanan orijinal tasarımların yöre halkına benimsetilmesi, sevdirilmesi, kültürlerine sahip çıkmaları sağlanmalıdır. Desen, ebat ve malzeme geleneksel yaygılarda günün şartlarına uydurulmalı, ancak olayın kültürel esprisi korunarak yapılması zorunludur. Yeni tasarımlar planlanırken başvuracağı bir merkezin bulunmaması, yeni tasarımların hem maddi, hem manevi açıdan külfetli olmasına ve zaman kaybına yol açmaktadır. Bunu önlemek için de iletişimi hızlandıracak, üretimi arttırabilecek kaynak ve zaman kaybını engelleyebilecek ve müşterinin arz-talebini karşılayabilecek danışmanlık servisi verebilecek ve aynı zamanda deneyimli tasarımcıları yetiştirebilecek desen bürolarının veya şirketlerinin kurulması gerekmektedir.

Üretici sebep-sonuçilişkisini danışacağı bir kurumdan yoksundur. Malzeme seçimi ve tasarım yaparken, hangi malzemenin hangi tasarımda ne gibi sonuçlar verdiğini ancak deneme yanılma sistemi ile görmektedir. Bu da büyük çapta kaynak israfına yol açmaktadır. Üretici, tasarımını önceden uzmanlarla tartışabilmeli, hangi hammaddeyi kaliteli ve ucuza nereden getirebileceğini, kiminle iş bağlantısı sağlayabileceğini, maliyeti nasıl düşürebileceğini, kaliteden taviz vermemeyi, uzmanlar bu konularda yol gösterebilmeli, seçenekler sunmalı, üreticiyi aydınlatmalıdır.

Tasarlanan ürün ise piyasanın talepleri yönünde olmalıdır. Dolayısı ile tasarım tamamen bir grup çalışması sorunudur. İnsanların koordineli ve bilinçli çalışması büyük önem taşımaktadır. Öncelikli olarak tüm dokumacılık tarihimizde uyguladığımız özgün desenleri toparlayacak, sınıflayacak, arşivleyecek bir çalışma başlatılmalı ancak kullanıcının kolayca faydalanacağı bir düzenleme getirmelidir, ikinci aşamada ise güncel sanat akımlarını takip edilerek, konuya yorum getiren, bu akımların günümüz dokumalarına uygulanabilmesi için konusun- da uzmanlaşmış bir çalışma grubunun oluşturulması gerekmektedir. ${ }^{13}$

Desen temini, tasarımı, öneriler ve arşiv konusundaki tüm iletişim bir merkezde odaklaştırılmalı, herkes bu adresten istediği desen, bilgi ve desteğini bir ücret karşılığında sağlamalıdır. Ancak burada firma bazında olaya bakacak olursak karşımıza bir sorun çıkabilir oda aynı desenin bir başka firma tarafından kullanılması. Bu sorunu da desenlerin tescil ettirilmesi ve bir desende belirli değişimler yapılmadan kullanılmasına izin vermemek olabilir ki zaten birçok firmada desenlerini tescil ettirmektedir. Böylece yeni tasarımlar hayat bulacaktır. Aynı zamanda dokuma sektöründe hem el dokumaları hem de makine dokumaları olarak üretilmesi gerekmektedir. Sonuç olarak önerilenler doğrultusunda büyük ölçüde el dokumalarının kaybolmasının önüne geçilebilinir.

\section{Kaynak Kişiler}

1. ADI SOYADI: Gülay KARAKULAK

DOĞUM YERI: Poyralı KÖyü (Kırklareli)

D. TARIHI: 1967

ÖĞRENIM: İlkokul

2. ADI-SOYADI: Hatice DALKIRAN

DOĞUM YERİ: Yenibedir Köyü

D. TARIIHI: 1948

ÖĞRENIM: İlkokul

3. ADI-SOYADI: Fatma ATAY

DOĞUM YERI: Soğucak Köyü

D. TARIHI: 1952

ÖĞRENIM: İlkokul

4. ADI-SOYADI: Fatma BAYKAL

DOĞUM YERI: Çeşmekolu Köyü

D. TARIHI: 1946

ÖĞRENIMI: İlkokul

5. ADI-SOYADI: Resmiye GÖKERBÜYÜK

DOĞUM YERI: Poyralı Köyü (Kırklareli)

D. TARIHI: 1946

ÖĞRENiMi: İlkokul

6. ADI-SOYADI: Zekeriya KURTULMUŞ

DOĞUM YERI: Lüleburgaz Çengelli Köyü

D. TARİHI: 1959

ÖĞRENIM: Erzurum Atatürk Üniversitesi Sanat Tarihi Bölümü

7. ADI-SOYADI: Yasin Güngören

DOĞUM YERİ: Lüleburgaz

D. TARİH: 05.08.1987

ÖĞRENIM: Orta Doğu Teknik Üniversitesi İngilizce Öğretmenliği Bölümü

8. http://www.tekirdagkulturturizm.gov.tr(2010)

9.http://pomakkulturu.blogspot.com/2007/04/pomak-eldokumalar.html(2010)

10. turkoloji.cu.edu.tr/.../mucella_kahveci_21. Yüzyıla girerken El Sanatları(2010)

$\overline{13}$ turkoloji.cu.edu.tr/.../mucella_kahveci_ 21. Yüzyıla girerken El Sanatları (2010) 